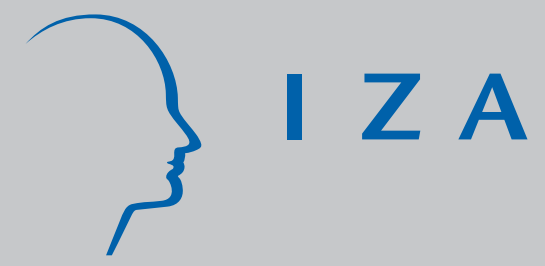

IZA DP No. 4901

Behavioral Foundations of Microcredit:

Experimental and Survey Evidence from Rural India

Michal Bauer

Julie Chytilová

Jonathan Morduch

April 2010 


\title{
Behavioral Foundations of Microcredit: Experimental and Survey Evidence from Rural India
}

\author{
Michal Bauer \\ Charles University, Prague, \\ CERGE-EI and IZA
}

Julie Chytilová

Charles University, Prague

Jonathan Morduch

New York University

Discussion Paper No. 4901

April 2010

IZA

P.O. Box 7240

53072 Bonn

Germany

Phone: +49-228-3894-0

Fax: +49-228-3894-180

E-mail: iza@iza.org

Any opinions expressed here are those of the author(s) and not those of IZA. Research published in this series may include views on policy, but the institute itself takes no institutional policy positions.

The Institute for the Study of Labor (IZA) in Bonn is a local and virtual international research center and a place of communication between science, politics and business. IZA is an independent nonprofit organization supported by Deutsche Post Foundation. The center is associated with the University of Bonn and offers a stimulating research environment through its international network, workshops and conferences, data service, project support, research visits and doctoral program. IZA engages in (i) original and internationally competitive research in all fields of labor economics, (ii) development of policy concepts, and (iii) dissemination of research results and concepts to the interested public.

IZA Discussion Papers often represent preliminary work and are circulated to encourage discussion. Citation of such a paper should account for its provisional character. A revised version may be available directly from the author. 
IZA Discussion Paper No. 4901

April 2010

\section{ABSTRACT \\ Behavioral Foundations of Microcredit: Experimental and Survey Evidence from Rural India}

Microcredit is an innovative financial tool designed to reduce poverty and fix credit market imperfections. We use experimental measures of time discounting and risk aversion for villagers in south India to highlight behavioral features of microcredit. Conditional on borrowing from any source, women with present-biased preferences are more likely than others to borrow through microcredit institutions. Microcredit contracts require loan repayments in regular, fixed installments and they harness peer pressure to encourage discipline. These innovations mirror mechanisms highlighted in behavioral approaches to saving, suggesting that microcredit's popularity stems partly from modes of encouragement and self-discipline absent in typical lending mechanisms.

JEL Classification: C93, D91, O12

Keywords: time preference, hyperbolic discounting, self-control, loan contracts, microfinance

Corresponding author:

Michal Bauer

Institute of Economic Studies

Charles University in Prague

Opletalova 26

Prague 1, 11000

Czech Republic

E-mail: bauerm@fsv.cuni.cz

\footnotetext{
* We thank BPKS and Caritas Prague for collaboration on the field work and J. Kabatová, D. Mascarenhas, S. Crasta and L. Perreira for excellent research assistance. We thank K. Basu, R. Filer, I. Gang, W. Greene, J. Hlaváček, D. Karlan, M. Mejstř́k, D. Munich, A. Ortmann, D. Ray, A. Schotter and $\mathrm{M}$. Skořepa for valuable comments in various stages of the project. We appreciate the financial support by a grant from the CERGE-EI Foundation under a program of the Global Development Network and by the IES/Charles University research framework 2005-10. We also appreciate support from the Gates Foundation through the Financial Access Initiative. All opinions and errors are our own.
} 
The Nobel Peace Prize in 2006 celebrated the potential of microcredit to transform the lives of small-scale entrepreneurs by providing access to small loans. Microcredit providers are drawn together by shared commitments to offer small-scale loans, serve the under-served, and use innovative contracts to compensate for the fact that most customers lack assets that can be used as collateral (Beatriz Armendáriz and Jonathan Morduch, 2005). Microcredit advocates argue that such access to credit will unleash the productive potential of poor households (Muhammad Yunus 2002).

The popularity of microcredit, though, poses a puzzle: if the untapped economic returns to borrowing are so high, why don’t households save their way out of credit constraints? New work in behavioral economics helps to answer that question by focusing on difficulties in self-control that undermine individuals' efforts to save, coupled with a lack of devices to compensate for behavioral weaknesses. Recent evidence shows that in the face of self-discipline problems, for example, accumulation can be aided by saving devices that require regular deposits at fixed intervals and limit withdrawals (Nava Ashraf, Dean Karlan, and Wesley Yin 2006) or that harness external pressure to encourage accumulation (Mary Kay Gugerty 2007). By this evidence, one of the hidden challenges faced by the poor is posed by limited access to such mechanisms (Daryl Collins et al. 2009).

We argue that behavioral insights suggest a new view of microcredit as well. The existing literature interprets microcredit as a novel solution to overcoming agency problems and reducing transaction costs. Those explanations, however, do not fully explain how microcredit practices deviate from standard modes of business lending. We draw links between features of microcredit loans and problems posed by present-biased preferencesi.e., by choices that emerge when, intellectually, people value future consumption but they nonetheless give in to immediate temptation. The internal tension is often depicted as a conflict between a patient "future self” and an impatient "present self” (Thomas C. Schelling 1984, Myron H. Strotz 1955, George W. Ainslie 1992), a tension captured parametrically by 
"hyperbolic" discount rates rather than standard linear discounting (David Laibson 1997). We show that women with present-biased preferences are particularly likely to be microcredit borrowers.

We study villagers in India who are the target customers of microcredit providers. The microcredit banks in the villages are run on a "self-help group” model promoted by the Government of India and inspired by Grameen Bank of Bangladesh, the co-winner of the 2006 Nobel Peace Prize. We conducted a series of "lab experiments in the field" designed to elicit measures of discounting and risk aversion for a random sample of 573 villagers spread across eighteen villages in two regions of Karnataka, a coastal state in South India. (These are “artefactual field experiments” in the classification scheme of Glenn W. Harrison and John A. List, 2004.) The questions were not hypothetical: the experiments concerned choices over relatively large stakes, as large as a week’s wage (as in Tomomi Tanaka, Colin Camerer, and Quang Nguyen, forthcoming, and Hans B. Binswanger 1980), and the structure of the questions allow us to infer intervals for discount rates and evidence of time inconsistency. We construct measures of present-biased time inconsistency and relate the measures of time discounting and risk aversion to survey data on economic and financial decisions of the households. The experiments identify roughly one third of the population as exhibiting choices consistent with present-bias, a fraction similar to those found in studies in the Philippines and the United States (Ashraf, Karlan, and Yin 2006; Stephan Meier and Charles Sprenger 2009).

In our sample, women in the present-biased group tend to hold a smaller share of their overall savings at home, a finding consistent with a desire to avoid the everyday temptation of depleting cash on hand. Women in the present-biased group are also more likely than other women to borrow. While we find that women are generally interested in opportunities to borrow, women with present-biased preferences are especially likely to do so via microcredit. The results are robust to controlling for their baseline degree of time discounting and a range 
of observable individual characteristics, attitude towards risk, village-level fixed effects, seasonal income patterns, health-related income shocks, and measures of intra-family decision-making power (i.e., "spousal control” difficulties).

The evidence is consistent with the notion that microcredit borrowing offers specific structure and support for people with self-discipline problems. In particular, microcredit contracts provide mechanisms typically associated with contractual savings devices. The most important features are the social elements embedded in group-based lending (weekly group meetings and public transactions) and the near-universal requirement that loans be repaid in regular, frequent, fixed installments over time. The data do not allow us to identify the specific mechanisms through which time-inconsistent preferences and microcredit demand are tied, but the pattern of results, when taken as a whole, cannot be easily explained by neoclassical assumptions, transactions costs, or intrahousehold conflicts. The evidence supports the argument that through microcredit structures, borrowers are able to achieve a goal usually associated with contractual saving: to exchange a steady series of small fixed payments for a substantial amount of income obtainable at a future date. In this sense, microcredit can serve as a substitute for structured saving devices.

The next section describes links between present-biased preferences, self-discipline problems, and the features of microcredit borrowing. Section II describes the economics of self-control. Section III describes the sample selection, experimental design for eliciting subjective discount rates, and the survey data. Section IV presents the empirical results on determinants of patience and time inconsistencies. Section V discusses how the experimental choices correlate with observed financial behavior and describes alternative hypotheses. Section VI concludes. 


\section{Present-bias and microcredit borrowing}

Microcredit programs focused on the poorest customers typically lend to customers through community organizations, with groups of neighbors formed to provide "solidarity” and transactions made at public meetings. In India, these organizations are most commonly "Selfhelp groups” (SHGs). SHGs are the major providers of financial services in our sample as well, although moneylenders, banks, and postal savings schemes also operate in the communities. SHG expansion has been driven by an initiative of the government's National Bank for Agriculture and Rural Development (NABARD) to encourage linkages between non-governmental organizations and commercial banks. By March 2007, 2.9 million SHGs were providing services to 41 million members (NABARD 2007).

SHGs are based on groups of low-income individuals formed voluntarily in communities, often facilitated by NGOs. The groups comprise 10-25 people, and groups gather regularly, typically every week, to pool their savings and lend from their accumulated pot to members at an interest rate designed to cover costs (Hans Deiter Seibel and Stephan Karduck 2005). Attendance is compulsory. The members select a group president and bookkeeper who help lead sessions. All transactions are made publicly in front of the entire group. The SHGs are permitted as informal entities to obtain bank loans and the whole group is responsible for the loan repayment. ${ }^{1}$

Such “joint-liability” provisions in group lending contracts are highlighted as ways to mitigate moral hazard and adverse selection in situations characterized by agency problems (Maitreesh Ghatak and Timothy Guinnane 1999), but agency theory explains only group-

\footnotetext{
${ }^{1}$ SHGs are based around "internal” and "external" accounts. The internal accounts are formed from members' pooled savings; the external accounts are financed by loans from commercial banks. Funds are lent to members from both accounts, and members monitor and enforce diligent repayment. For "internal" loans, incentives are given by the risk of losing savings and for "external" loans incentives are created by explicit joint liability mechanisms. We also note that all SHG members must deposit regularly into compulsory savings accounts (deposits average Rs. 40 per month; at the time of our study, the official exchange rate was 40.6 Indian rupees per US dollar). These accounts have tight withdrawal restrictions: savings may only be withdrawn when a member leaves a group or if there are exceptional circumstances. This kind of forced saving aids the SHG by creating collateral that can be tapped in times of trouble, but it is of limited immediate value as savings for customers.
} 
based contracts, not group meetings. When Grameen Bank dropped joint-liability contracts under their Grameen II re-formulation, for example, they nevertheless kept group meetings (Daryl Collins et al. 2009). Group meetings have the advantage of reducing transactions costs for loan officers by gathering customers in one place at one time to quickly complete business. The evidence here suggests that transaction cost reductions may not be necessary to explain the persistence of groups. In finding that people with time-inconsistent preferences are more likely to borrow from microcredit organizations than other providers, the data suggests that purely social elements_-including the common requirement that repayments be made in public_-may also explain the persistence of group-based lending (even after groupbased contracts are dropped). Time-inconsistent individuals may value the social pressure from other group-members as a way to discipline their choices.

A second less-noted feature of microcredit contracts is that borrowers must typically repay loans in weekly installments beginning at the very start of the loan, well before investments can be expected to bear fruit (Stuart Rutherford 2000). This feature cannot be explained by simple efforts to reduce transactions costs since the practice increases costs. The structure is particularly surprising under the traditional explanation that microcredit loans are made to support business investment. The weekly structure implies that payments for early installments typically come, at least in part, from other income earned by households, such as from wage work. This part of the repayment process thus looks and feels much like the process of saving in regular increments from earned income, and the regularity and frequency of the small installments provides structure well beyond that of a typical business loan. In a (neoclassical) textbook contract for a business loan, by contrast, the principal and interest are paid in a single, large payment after profits are reaped. ${ }^{2}$ The fact that the payments are broken down into many small pieces is consistent with the prevalence of saving difficulties.

\footnotetext{
${ }^{2}$ See Armendáriz and Morduch (2005) on the logic of microcredit repayment schedules, and Erica Field and Rohini Pande (2008) for a field experiment from urban India.
} 
In our sample, two thirds of SHG participants have a loan, with an average size of Rs. 6,708 (about \$170). The interest rate charged by banks to SHGs is about 20 percent annually; the interest rate for individual loans is at the discretion of SHGs and varies. Recent surveys of SHGs show that more than 80 percent of loans were self-reported as being used for production or other purposes—-notably agricultural production, animal husbandry, and microenterprise--rather than consumption (Consultative Group to Assist the Poor 2007, JeanMarie Baland, Rohini Somanathan, and Loren Vandewalle 2008). We show below that people who are more patient borrow more, a pattern consistent with the notion that the loans are mainly used for productive investments and other forward-looking purposes, not for immediate consumption. The argument here is that borrowing for investment is done in ways that look like the process of contractual saving since both deliver benefits in the future.

A third, common microcredit feature is repeat borrowing. Once a loan is repaid in full, microcredit borrowers are generally expected to take another loan immediately, such that nearly all the time borrowers have outstanding credit. The expectation of continuous borrowing, which is again unlike a typical business loan relationship, further blurs the distinction between credit and saving. After the initial loan is disbursed to a customer, the process of repaying loan installments and receiving disbursements is observationally similar to the process of building up savings in regular increments followed by regular lump-sum withdrawals—although with different cost implications since borrowing requires interest payments. To draw the link, Rutherford (2000) describes traditional saving behavior as "saving up" and borrowing in this form as "saving down.”

A fourth link to saving difficulties is given by the fact that microcredit institutions tend to serve far more women than men. Ninety-five percent of Grameen Bank’s customers are women, for example. SHGs also predominantly attract women, although no explicit targeting is built into the program design. In our sample, 76 percent of SHG members are women. In terms of the population, 63 percent of women in our sample are SHG members 
and only 21 percent of men. The study on saving behavior by Ashraf, Karlan and Yin (2006)

finds that women with time-inconsistent preferences are more likely to take-up structured saving products than other women - and the effect is not found for men. Similarly, our key results below hold for women only. ${ }^{3}$

\section{Self-Control and Financial Behavior}

The degree of time discounting is essential in making saving and investment decisions. The behavioral economics literature has made much of experimental evidence showing that in practice discount rates often vary with the time frame (Shane Frederick, George Lowenstein, and Ted O’Donoghue 2002). In particular, people are often more impatient with regard to current trade-offs than with regard to future tradeoffs (Strotz 1955, Ainslie 1992), a notion termed “present-bias” and reflected in hyperbolic (or "quasi-hyperbolic”) time discount functions (Laibson 1997).

Present-biased preferences create a tension between future plans and current actions, and create a time inconsistency problem. For example, present-biased individuals may look to the future and determine that in one year's time, it would be best to put aside some money for saving. But when the next year arrives and the choice is revisited, their decision may be reversed, over-powered by the temptation to consume immediately. If individuals anticipate this kind of preference reversal, they may demand a commitment to "tie their hands" now, locking in the original choice to save (Sendhil Mullainathan 2005).

One way to do that is to create a public commitment to save or to enter into an explicit saving contract. In richer countries, the most common mechanism is direct-deposited pension accounts and stop orders. In poorer communities, a range of informal devices share these features, including community-run savings clubs and rotating savings and credit associations.

\footnotetext{
${ }^{3}$ Pascaline Dupas and Jonathan Robinson (2009) find that women with present-biased preferences are slightly less likely to take-up "unstructured” saving products than other women in Kenya. The effect is negative but not statistically significant; the saving product carries no interest and has withdrawal fees, but has no deposit schedule and no provision to foster social pressure from peers.
} 
But such informal devices can be unreliable (prone to fall apart and at risk of theft), and they tend to work better for raising small sums than for large (Collins et al. 2009).

If individuals with present-biased preferences are "sophisticated” (in the sense that they understand their weakness to temptation) but lack adequate tools to impose self-control-or are "naïve” (and thus do not anticipate their inconsistencies)--they will repeatedly make decisions that they later regret (Ted O’Donoghue and Matthew Rabin 1999). If present-biased individuals are sophisticated, they may also make choices that are not obviously rational to outsiders. Karna Basu (2007), for example, provides a theoretical explanation for why individuals with present-biased preferences are apt to simultaneously save and borrow—rather than simply dis-save. When one dis-saves, it is typically up to the individual to re-build the accumulated capital without external support. But when one borrows, the lender usually structures and monitors repayments to ensure speedy and on-time repayments. For some, the structure and monitoring may feel unduly onerous, but for someone with present-biased preferences, the structure and monitoring can offer a valuable mechanism for achieving financial discipline.

Ashraf, Karlan and Yin (2006) show how commitment features can be built into formal-sector saving products that combine security, convenience, and the ability to handle larger sums. They demonstrate that some bank customers (with existing savings accounts) shift behavior when given the choice to also opt into savings accounts that incorporate commitments to save and that limit withdrawals. Their experiment with a rural bank in the Philippines focuses on new accounts that give the chance to commit to deposit money until either a given date or a given sum was saved. In all other regards, including the interest rate, the new accounts were identical to those already held by the sample. The researchers find that 28 percent of customers offered the "commitment” product accepted it. Women who demanded the product were more likely to have present-biased time preferences—and use of the accounts increased their short-term saving by about 80 percent. 
Present-biased preferences have been invoked to explain a growing range of economic puzzles in poor countries. Esther Duflo, Michael Kremer and Jonathan Robinson (2005) observe patterns consistent with sophisticated present-biased preferences in their field experiments on fertilizer adoption. Mullainathan (2005) argues that present-biased preferences help explain erratic school attendance. Gugerty (2007) similarly interprets the widespread use of informal rotating savings and credit associations (ROSCAs) as a commitment device to overcome present-bias and the related time inconsistency faced by savers. ${ }^{4}$ She observes that participants in Kenya value public pressure to make regular saving deposits; as some ROSCA participants put it, “you can’t save alone.” Similarly, as a poor, elderly woman in South Africa noted, stressing the value of social mechanisms that sustained her neighborhood saving club: “You feel compelled to contribute your payment. If you don’t do that, [it] is like you are letting your friends down” (Collins et al. 2009, p. 114). In keeping with this, Armendáriz and Morduch (2005) and Basu (2008) invoke the desire to overcome savings difficulties as a rationale for why popular informal group-based savings and borrowing institutions, such as ROSCAs, are able to find the necessary participants.

We turn here to the link between present-biased preferences and borrowing decisions. As noted, both savings with commitment and paying credit in installments operate by pressuring individuals to follow an intended course of action by taking regular steps (Strotz 1955, Laibson 1997). Borrowing, though, is a roundabout way to save, and it entails paying interest.

While most people expect to earn interest on saving deposits, poor households may pay to save when options are limited (Collins et al. 2009). The saving device tested in the Philippines, for example, was taken up by sub-set of women with present-biased preferences,

\footnotetext{
${ }^{4}$ Tanaka et al. (2009) test the link between present-biased preferences and ROSCA participation. They find that present-biased individuals are more likely to participate in ROSCAs with more frequent meetings (i.e., daily or weekly) than in ROSCAs that are held monthly. They also find that present-biased women are more likely to participate in bidding ROSCAs, but they are less likely to participate in ROSCAs with a fixed disbursement order.
} 
although the device was costly to them (relative to the accounts they already had) in that the new accounts offer no extra compensation for the associated illiquidity. Similarly, local deposit collectors are a common part of the informal financial sector, charging customers a substantial fee for a simple, secure, disciplined way to save. One calculation shows that in South India, a deposit collector who takes savings from her customers each day, returning the accumulation after 220 days, charges depositors a fee equivalent to 30 percent of deposits on an annualized basis (Rutherford 2000). Given such limited options, microcredit borrowing can be seen as offering another costly accumulation device, built on the common features of microcredit contracts - especially repaying in public and in regular, frequent, and small installments - that mirror mechanisms highlighted in behavioral approaches to saving. In the

present study, we explicitly test the proposition that individuals identified as having presentbiased preferences are more likely to use loan products that feature structure and discipline. As Siwan Anderson and Jean-Marie Baland (2002) argue based on evidence from Kenya, the central discipline problem may instead involve protecting savings from spouses, with whom the saver has conflicting preferences. It is an important and plausible argument, but in the work below we find that the effect of present-biased preferences is robust to including measures of individual autonomy and power within households.

\section{Experimental and survey design}

Although much has been written about time discounting, experimental evidence is largely limited to laboratory environments in developed countries. Significant contributions are Glenn W. Harrison, Morten I. Lau, and Melonie B. Williams (2002) and Uwe Sunde et al. (forthcoming) who estimate the subjective discount rate among a representative sample of the Danish and German populations. Several innovative studies, typically in low-income countries, employ experimental tasks to predict behavior outside of labs to study motivations 
behind behavioral choices. ${ }^{5}$ In our study we are primarily interested in whether people with present-biased preferences behave differently from those having time-consistent preferences.

\section{A. Sample selection}

The survey design generated a varied sample of the rural population of Karnataka. Data were collected in June 2007 in cooperation with BPKS, an Indian NGO in Honavar and Haliyal taluks (a taluk is an administrative unit akin to a county, part of a larger district within a state).

Honavar is a coastal region and, of the two, is more developed in terms of infrastructure, market access and access to education and financial facilities. Nine villages were selected from each taluk, and 35 people were selected in each village using a random walk method. ${ }^{6}$ Those identified were invited to participate in the study, and 90 percent did. The total number of participants was 573, with no fewer than 25 participants per village. We used village meeting halls, typically schools, as field labs. The very high response rate stemmed in part from the support of village heads. Self-selection concerns are limited by the high take-up rates.

Table 1 compares the sample characteristics with Karnataka averages from 2001, restricted to the population older than 15 years. The average age and education levels are nearly equal, and the proportion of illiterate respondents is slightly lower in our sample (40 percent compared with 43 percent in the entire state). Age of marriage is typically higher in

\footnotetext{
${ }^{5}$ For example, Binswanger (1980) and Elaine Liu (2008) elicit individual attitudes to risk and observe correlations with agricultural behavior. Dean Karlan (2005) uses the results of trust games to predict default among clients of FINCA. Tanaka, Cameron, and Nguyen (forthcoming) take an approach similar to ours. Duncan Thomas and Amar Hamoudi (2006) measure discounting, risk aversion, and altruism to study motivations behind inter-generational exchanges.

${ }^{6}$ The villages were randomly selected based on the 2001 Indian Census database; however, in three villages in each taluk the BPKS lacked good access to the village head, jeopardizing the ability to carry-out the experiments. These six villages were replaced with other villages that were similar in size, distance to town and educational facilities to the ones originally selected. Lacking a full census of residents from which to draw a random sample within each village, enumerators started walking from a center of a village toward the outside, moving in the direction of the sun. Enumerators attempted to visit every second house on the right hand side, randomly selecting interviewees from members above 15 years of age. At the approximate end of the village the assistants turned right and continued the walk until they had invited the requested number of participants for a research meeting. The result was a diverse and relatively representative (but not strictly random) sample within villages.
} 
urban areas that are included in the Karnataka average, while our respondents are villagers and therefore more likely to be married. Although the selection strategy does not generate a representative sample of the rural population of Karnataka, the sample captures its variety.

\section{B. Measuring discount rates and risk aversion}

We used a simple protocol to elicit discount rates, drawing on practices common in developed and developing countries (e.g. Harrison, Lau, and Williams 2002; Tanaka, Cameron, and Nguyen, forthcoming). ${ }^{7}$ Respondents were asked to choose between receiving smaller amount earlier in time or larger amounts with three months delay. We start with: "Do you prefer Rs. 250 tomorrow or Rs. 265 three months later?”

We posed five such questions to each individual, with each question increasing the future amount up to Rs. 375 while keeping the earlier amount constant. We thus made the choice to delay increasingly more attractive in each subsequent binary choice (left-hand side of Table 2 gives the choices). The point at which an individual switches from choosing the earlier reward to the future reward gives an interval of her discount rate. In the analysis we use the arithmetic means of these intervals to approximate individual discount rates (for specific values see Appendix A). Five percent of respondents switched more than once, and nothing could be inferred about their discount rate. Such choices are uncorrelated with observable characteristics and the respondents were excluded from the analysis, reducing our sample to 544.

The same set of binary choices was also offered at a future time frame (as in Ashraf, et al. 2006). Here, we started with: “Do you prefer to receive Rs. 250 in one year’s time or Rs. 265 in one year and three months?” (See right-hand side of Table 2) We denote the discount rate calculated from the current tradeoffs as the "current discount rate” or "current patience”

\footnotetext{
${ }^{7}$ In their surveying article Juan C. Cardenas and Jeffrey P. Carpenter (2008) classify this methodology as the “choice task method.” For a discussion on relative advantages of using “choices task method” vs. alternative “matching-task method” see Frederick, Lowenstein, and O’Donoghue (2002). Our decision was largely made on the basis of simplicity given the low education levels in the area.
} 
and that calculated from the future tradeoffs as the "future discount rate" or "future patience". Inconsistencies provide evidence of present-biased preferences, as discussed in the next section.

Several design features in the elicitation methodology allow us to identify time preference reversals (differences between current and future discount rates) with greater confidence. First, we shifted the time frame by exactly one year to reduce the effects of seasonality of agricultural incomes and season-specific expenditures (e.g., annual celebrations).

Second, we introduced a short delay in the current income option in the earlier time frame; specifically, we asked respondents about receiving the Rs. 250 tomorrow rather than today. This "front end delay" method should control for potential confounds due to lower credibility and higher transaction costs associated with future payments (it is used, for example, by Harrison, Lau, and Williams 2002; John Pender 1996). If participants lack confidence that they will receive a reward in the future, they may prefer a current reward irrespective of their actual discount rate. Therefore no payments were made on the day of the experimental session. Instead, participants were making choices between Rs. 250 delivered the next day and a higher amount delivered after three months. The approach also reduces transaction costs differentials between the options; since all payments are in the future, participants should assign the same subjective transaction costs to both options. The methodological trade-off is that the approach to measuring present-bias does not strictly mimic the interpretation of "hyperbolic" preferences that centers on the temptation to consume today rather than later. If self-discipline problems are restricted only to temptations to consume today (rather than to consume tomorrow or at some other moment that is very soon relative to other options), the results here will under-count the incidence of presentbiased ("hyperbolic") preferences. In this sense, we opt for a conservative procedure. 
Third, the set of binary choices in the future time period (with a one year delay) were asked immediately after the set of choices offered in the earlier time frame. This sequencing (and the use of the "front end delay" method) should also lead to a conservative estimate of the likelihood of time preference reversals since it biases toward consistency.

Individual attitudes to risk were elicited in order to control for the curvature of utility function. We used a near replication of the simple protocol designed by Binswanger (1980) in his study of villagers in South India and later used by Abigail Barr and Garance Genicot (2008) in Zimbabwe. Each participant was asked to select one out of six different gambles. Every gamble yielded either a high or a low payoff with a probability 0.5 . In each subsequent gamble the expected value increased jointly with the variance. The sizes of the prize were set at the level of time discounting choices. The expected value of the least risky gamble was set at Rs. 250, and the higher payoff in the most risky gamble was Rs. 1000. The prizes for all the gambles are in Appendix A. ${ }^{8}$

Before the experimental questions, the experimenter explained the types of choices the participants would make and how payment would work. ${ }^{9}$ The procedure was designed to motivate participants to make choices according to their true preferences in each choice. Much care has been devoted to ensuring a correct understanding, given the high proportion of illiterate respondents. Before asking the participants to make actual choices, the experimenter simulated the randomization procedure and answered all questions. Ten trained research assistants were at hand to help illiterate participants with recording experimental choices and completing questionnaires. Participants were told that the experiments would involve multiple choices and that one of the choices would be potentially relevant for their payoff. The

\footnotetext{
${ }^{8}$ In addition, we used one more set of prizes to elicit risk aversion. The relative proportions of the amounts in the gambles were exactly the same as in the first set, but the size of the amounts was lower. In the analysis we control for risk aversion inferred from gambles with higher amounts which were set on a level comparable to time discounting choices. This measure of risk aversion is better able to capture the potential effect of the curvature of the utility function on the measures of discount rates.

${ }^{9}$ In 12 villages, the experimenter was the director of the cooperating NGO, in six remaining villages the main instructor was the associate director who was also present at previous meetings as a research assistant. The results reported below do not change substantively after controlling for experimenter effect (not reported).
} 
participants knew that at the end of the meeting it would be randomly determined whether they would be paid (with probability equal to 20 percent) and according to which choice they would be paid. The randomization was based on tossing nametags and numbered ping-pong balls. $^{10}$

At the end of a session, randomly selected respondents were rewarded. Payments relating to risk aversion questions were disbursed immediately. For time discounting questions, winning participants received a cash certificate signed by the chief of the NGO, a local leader and a social worker familiar in the community. The prizes were deposited by the NGO and the social worker was responsible to deliver the amount specified in the cash certificate at the given date. $^{11}$

\section{Survey data}

Appendix A describes definitions of variables used in the analysis. A wide range of information on individual characteristics was collected such as age, education, family background (marital status, household head, and woman’s position in the household), economic conditions and financial behavior. We constructed an index approximating wealth using principal components analysis based on information about items at home, characteristics of the house, and land possession. A set of questions on decision-making power and on attitudes about wife beating was used to approximate women's position within households (Jensen and Oster 2007). Again we used principle components to construct an index. Data on individual savings in a bank, a post office, at home and participation in SHGs together with information on borrowing were collected as measures of individual financial behavior.

\footnotetext{
${ }^{10}$ Another possible way of randomization would be to let each participants use a randomization device which would determine if she would be paid or not (as in e.g. Sunde et al., forthcoming, who set the probability of being paid to 1/7). To make the process simple, we announced the number of participants who would be randomly selected for payment.

${ }^{11}$ Everyone was also given a participation fee amounting Rs. 60 to compensate for opportunity costs (daily income). One session lasted on average four hours and these payments were made upon completion of the entire session.
} 


\section{Determinants of time discounting}

We focus on four characteristics resulting from the experiments: "current patience" (based on the choice whether to be rewarded tomorrow or in three months, as reflected in the left hand side of Table 2), "future patience" (based on the choice to be rewarded in 12 months or in 15 months, as seen on the right-hand side of Table 2), present-biased time inconsistency (hyperbolic discounting) and future-biased time inconsistency ("patient now, but impatient in the future").

Almost one third of individuals have present-biased time preferences. We interpret the choices as present-biased if the inferred current discount rate is higher than the future discount rate. An individual with present-biased preferences is more impatient with respect to choices affecting consumption very soon (literally tomorrow) than with respect to choices that will play out in the future (literally in one year).

We further distinguish between individuals with “weakly present-biased” preferences and “strongly present-biased” preferences. Weakly present-biased preferences reflect small differences between current and future discount rates, resulting from choosing the future reward only one binary choice earlier in future time frame (Table 2, right-hand side) compared to earlier time frame (Table 2, left-hand side). If the difference is larger, a person is regarded as having strongly present-biased preferences.

Table 3 illustrates definitions of the time inconsistencies and describes their distribution. The current discount rate is on the vertical axis and the future rate is on the horizontal axis. Cells on the diagonal (where the current discount rate equals the future discount rate) represent individuals with time consistent preferences. Below the diagonal, preferences are present-biased. An individual is defined as “weakly present-biased” if she made a combination of choices that are next to the diagonal and as "strongly present-biased" 
if combinations lie further below the diagonal. ${ }^{12}$ Above the diagonal are individuals with

future-biased time inconsistency, in which individuals are more patient now than in the future.

Disaggregating the one third of individuals with present-biased time preferences yields that 19.9 percent of the sample are strongly present-biased and 13.2 percent are weakly

present-biased. In contrast, fewer than 10 percent of individuals are more patient now than in the future. (As noted in the introduction, these proportions are similar to those found by

Ashraf et al. 2006 in the Philippines and by Meier and Sprenger 2009 in the United States.)

\section{A. Regression analysis of discount rates}

In this section we examine how levels of risk aversion and observable characteristics (gender, age, education, wealth, income fluctuations, family status) predict these traits. In the regression analysis we use OLS for discount rates and probits for time preference reversals. ${ }^{13}$ In the first two columns of Table 4, the dependent variable is the current discount rate, and it is the future discount rate in the next two columns. As in Kris N. Kirby et al. (2002) and Michal Bauer and Julie Chytilová (forthcoming), we find that more educated individuals are more patient, an effect that is particularly strong for men. Each additional year of schooling is associated with a decrease in the current discount rate of 1.3 percentage points and a decrease in the future rate of 1.5 percentage points. ${ }^{14}$

We don’t find direct evidence that discount rates are a function of liquidity constraints (as in William Adams, Liran Einav and Jonathan Levin 2009). To test this hypothesis, we

\footnotetext{
12 As a robustness check, we pool the strongly and weakly present-biased individuals into one group and find qualitatively similar results (web Appendix: Tables A11-A13).

${ }^{13}$ Using an ordered probit instead of OLS yields comparable results (results reported in the web Appendix: Table A23).

${ }^{14}$ We also find that women generally make more patient choices than men. The "current" three-month discount rate is 27.0 percent for men but only 21.8 percent for women. For the "future" discount rate the averages are 22.6 percent and 15.9 percent respectively. (For both discount rates the differences are significant at the 1 percent level.) The results accord with evidence on behavior from developing countries showing that income in the hands of women is more likely to be used for future-oriented expenditures rather than current consumption (Duncan Thomas 1990; Agnes Quisumbing and John Maluccio 2003) and with the positive experience of microcredit institutions with borrowing to women (Yunus, 2002). The numbers were also consistent with a casual observation made during the experimental meetings. The participants were given a lunch, and we noticed that most women did not eat the meal, but waited until the end of the session and brought it home to share with their children. Men ate the lunch immediately.
} 
asked participants which months are their high-income and low-income months. Individuals who have relatively low income at the time of the experiment relative to three months later are not more impatient. In fact, for men the coefficient on the future discount rate takes the opposite sign to that predicted by the liquidity constraint hypothesis (and is significant at the 10 percent level).

\section{B. Determinants of present-biased preferences}

Columns 5-8 of Table 4 show the determinants of present-biased preferences. Few observable characteristics explain present-biased time inconsistency. Neither education, wealth, nor seasonality of income predict present-biased time inconsistency at conventional levels of statistical significance. Only male farmers are more likely to have strongly present-biased preferences, but the coefficient takes the opposite sign and is not statistically significant in the regression on having weakly present-biased preferences. These results are similar to estimates of Ashraf, Karlan, and Yin (2006) and other psychological studies on impulsiveness that find little association with observable characteristics.

There are two major concerns to consider before interpreting the observed reversals as indications of present-biased preferences. First, the preference reversals may mirror cash flow fluctuations between the earlier and the delayed time frame if individuals were liquidity constrained. Agricultural income is likely to fluctuate between seasons within a particular year. Similarly, local celebrations are organized on an annual basis with fixed dates. To address this concern, we deliberately shifted the time frame by exactly one year. After controlling for village fixed effects (as we do in all estimates), the concern reduces to the role of idiosyncratic income or expenditure fluctuations across years, such as those resulting from extremely adverse weather conditions. If farmers experienced or expected relatively bad harvest this year compared to their usual harvest, they could become more impatient now than in the future. According to official standards and data from the Directorate of Economics and 
Statistics, Government of Karnataka, the cumulated rainfall since the monsoon until the end of the survey was “normal” in both Honavar and Haliyal Taluks, and when asked directly, most of local leaders indicated that the present rainfall did not substantially differ from previous years. As a further check, participants were asked to select the major unexpected shock during the last five years; 42 percent selected low harvest due to bad weather and this characteristic fails to predict preference reversals.

Second, the reversals may reflect expected transaction costs and diminished trust that future rewards will be received, resulting in a higher discount rate now and lower discounting in the future. As noted earlier, we mitigate this concern by designing the binary choices so that there are no immediate payments and by putting the responsibility for future payments into the hands of respected individuals familiar to the participants. In order to test if the reversal is driven by lack of trust, we also included three questions from the General Social Survey (GSS) on "trust”, “fairness” and "helping” into our survey. An index from these questions is uncorrelated with both weakly and strongly present-biased preferences (pvalue $=0.39$ and 0.34 , respectively) as are the elements taken separately. Similarly, individuals with no previous interaction with the cooperating NGO -- and hence those presumably less inclined to trust it -- are not more likely to have present-biased preferences. Moreover, if the credibility issue was the driver of time preference reversal, the present-biased preferences should not be correlated with financial behavior, which contradicts our observations shown in the next section.

Columns 9 and 10 of Table 4 show how individual characteristics predict being patient now and impatient in the future. There is no clear behavioral explanation for this reversal and our data also don't give a clear indication. We show in the next section that women with this type of preference are substantially less financially active in terms of both borrowing and saving. In column 9 of Table 4 we observe that less wealthy women are more likely to exhibit this reversal (the result is marginally significant). The most plausible explanation is 
differential uncertainty about cash flow now and after one year. If a person near the subsistence level knows her cash flow is now above subsistence but feels uncertain about cash flow next year, she may become less impatient about her choices now than in the future. Unfortunately this is impossible to test without data on the relative riskiness of individual income streams.

\section{Discounting and Financial Decisions}

The heart of the paper links the non-laboratory borrowing and savings decisions to the experimental choices observed in the field labs. We test several specific hypotheses about the financial behavior of individuals with present-biased preferences, that, taken together, support the interpretation of microcredit as a disciplined though costly savings device for individuals with self-control problems. Theory predicts that individuals with present-biased preferences have saving difficulties and save less than people with time consistent preferences. If they are self-aware, they recognize the tension between their current and future levels of patience and adjust their financial strategies. Specifically, self-aware people with present-biased timeinconsistent preferences are likely to reduce the share of savings held at home (where temptation is greatest) and, we argue, seek commitment devices like SHG loans. If contractual savings devices had been available in this sample, we would expect to see demand for them as well.

\section{A. Savings and borrowing: Regression results}

In the textbook case of financial decision-making with time consistent preferences, the choices of individual $i$ in village $v$ depend on her discount rate $\delta_{i v}^{t}$, her level of risk aversion $R_{i v}$, observed and unobserved conditioning factors, $X_{i v}$ and $\varepsilon_{i v}$, and fixed village characteristics $v_{i}$. Thus the outcome $Y_{i v}$ is a simple function: 


$$
Y_{i v}=f\left(\delta_{i v}^{t}, R_{i v}, X_{i v}, v_{i}, \varepsilon_{i v}\right)
$$

We capture these relationships in a linear regression specification, adding variables to capture departures from the textbook case:

$$
Y_{i v}=\beta_{0}+\beta_{1} \delta_{i v}^{t}+\beta_{2} P_{i v}^{s}+\beta_{3} P_{i v}^{w}+\beta_{4} F_{i v}+\beta_{5} R_{i v}+\beta_{6} X_{i v}+\sum_{v=1}^{17} \gamma_{v} D_{i v}+\varepsilon_{i v}
$$

where $Y_{i v}$ is the financial behavior, $\delta_{i v}^{t}$ is a discount rate, $P_{i v}^{s}$ is a dummy indicating a strongly present-biased individual, $P_{i v}^{w}$ is a dummy for being weakly present-biased, $F_{i v}$ is a dummy for future-biased time inconsistency (dummy for time consistent preferences is omitted), $R_{i v}$ is a vector of dummies for risk aversion, $X_{i v}$ is a vector of observable characteristics, $D_{i v}$ is a vector of village dummies and $\varepsilon_{i v}$ is an error term for individual $i$.

The central interest is with $\beta_{2}$ and $\beta_{3}$, the coefficients on the indicators for having strongly or weakly present-biased preferences (respectively). Their size and sign depend on which measure of the discount rate $\delta_{i v}^{t}$ is included in the specific regression, and the resulting patterns illuminate households' "sophistication” and ability to exercise self-control. ${ }^{15}$ Regressions are thus run separately for the two measures of the discount rate. The first is what we have been calling current patience (left hand side, Table 2): $\delta_{i v}^{t}=\delta_{i v}^{0}$. The second measure is future patience (right hand side, Table 2): $\delta_{i v}^{t}=\delta_{i v}^{1}$.

When we control for the current discount rate $\left(\delta_{i v}^{0}\right)$ in the regression, the coefficients $\beta_{2}$ and $\beta_{3}$ on the present-biased indicators estimate the difference in saving levels for a present-biased person (for whom $\delta_{i v}^{0}>\delta_{i v}^{1}$ ) relative to someone similar in terms of the current discount rate but with time consistent preferences $\left(\delta_{i v}^{0}=\delta_{i v}^{1}\right)$. For a present-biased population that is “naïve”, immediate concerns over-ride preferences they hold with regard to the future

\footnotetext{
${ }^{15}$ Ashraf et al. (2006) use a related specification in their analysis of a commitment savings product, in which both current and future discount rates are included simultaneously and the dummy for future-biased preferences is omitted. Their coefficients have a slightly different interpretation, but the main results hold independent of the specification. For our estimates using their specification see web Appendix, Table A14-A16.
} 
(O'Donoghue and Rabin 1999). We thus expect them to completely give in to their immediate temptations, $\beta_{2}=\beta_{3}=0$. This form of naïve, present-biased individual will act as if their preferences are time consistent at the level given by their “current” discount rate. But it’s more likely that some self-control is possible, and positive coefficients on the present-biased indicators ( $\beta_{2}$ and $\beta_{3}$ ) indicate that the current self does not fully prevail.

In contrast, if the present-biased individual is "sophisticated", they appreciate the implications of $\delta_{i v}^{0} \neq \delta_{i v}^{1}$, and adjust their behavior to the extent they can given the available mechanisms. Commitment mechanisms might allow them to save fully according to their plans, in which case a regression that includes the future discount rate $\left(\delta_{i v}^{1}\right)$ yields $\beta_{2}=\beta_{3}=0$. In this case, temptations would be completely held at bay.

“Sophisticated” individuals with present-biased preferences might also overcompensate by applying commitment devices that lead to even higher levels of saving than their future discount rates would suggest (a class of "sophisticated” behavior highlighted by O’Donoghue and Rabin 1999); here, $\beta_{2}>\beta_{3}>0$ in the regression anchored by the future discount rate $\delta_{i v}^{1}$. An alternative situation, in which "sophisticated" individuals have no way to commit to saving, could result in their giving up and saving even less than the level predicted by current patience (i.e., $\beta_{2}, \beta_{3}<0$ when controlling for current discount rate). Here, individuals recognize that in the future they will have to permanently fight not to overspend so they choose not to save so much in the first place (O’Donoghue and Rabin 1999).

These same patterns should hold for microcredit production loans, given the premise that they are investments and, due to the structure of microcredit contracts, entail delayed gratification. As argued earlier, the structure of microcredit loans can make them useful commitment devices for individuals seeking better ways to accumulate. Using a similar argument as in the case of saving with commitment, sophisticated individuals with presentbiased preferences would then borrow as predicted by the preferences of their future selves or 
even more than that if they overcompensated (i.e., $\beta_{2}>\beta_{3} \geq 0$ when controlling for $\delta_{i v}^{1}$ ). The same pattern could reflect the need by present-biased borrowers to compensate for their saving difficulties. If this latter motivation drives behavior, then present-biased preferences should increase the demand for all loans, rather than microcredit loans specifically, a result we do not find for women.

\section{B. Saving}

Present-biased preferences matter for overall saving levels of women. On average, the level of self-reported financial savings (in a bank, post office, SHG and at home) is Rs. 2,016 for women (Table 5). ${ }^{16}$ But the average masks an important difference: the total savings of women with time-consistent preferences are Rs. 2,305, but women with strongly presentbiased preferences save only Rs. 1,636. Men on average save Rs. 3,113, and we observe no significant difference for men who have time consistent preferences versus those who don't, suggesting that men may have better mechanisms for addressing time inconsistencies (in line with Ashraf, Karlan, and Yin 2006, and Dupas and Robinson 2008).

Table 6 shows these patterns in a multivariate context. After controlling for other variables we find that present-biased women save substantially less than their future discount rate $\delta_{i}^{1}$ suggests (Table 6, column 3): $\beta_{2}<0$. When controlling for their current discount rate $\delta_{i}^{0}$, the coefficient for being strongly present-biased remains negative but is a third the size and not statistically significant (column 1): women’s saving behavior follows their current patience level more closely than their future patience level. The results are qualitatively similar for weakly present-biased women, though measured with greater noise.

\footnotetext{
${ }^{16}$ In the analysis we focus only on individual financial savings and omit other possible forms of saving, such as livestock and jewelry purchases, which are difficult to value. The participants were asked directly whether and how much they save in places that are most relevant in rural Karnataka: at home and in a bank, a post office, or an SHG. These are, of course, very sensitive numbers and vulnerable to measurement error. We thus put special emphasis on careful explanation of the purpose of the study and confidentiality. Below, we report correlations with measures of discounting. Note that we also observe other intuitive relationships with respect to individual characteristics (not reported): total savings are higher for wealthier and middle-aged individuals (around 42 years).
} 
As expected, wealthier individuals report higher saving levels and more educated men also report significantly higher savings. For men, the coefficients on strongly present-biased preferences suggest the ability to rein in self-control problems but are not statistically significant. The overall pattern of results is consistent with behavior of both "naïve” and “sophisticated” present-biased individuals who lack a suitable savings device (or use alternative devices to accumulate). To explore further, we study the purpose of savings and composition of savings.

Columns 5 to 8 show that men and women who are more patient are more likely to have "future-oriented" savings goals, i.e. $\beta_{1}<0$. We define the purpose of savings as being “future-oriented” if it is primarily tagged to pay for agricultural investment, business, education, or medical procedures; the indicator of future-orientation equals zero if savings are mainly for basic consumption (celebrations, personal items, household equipment). More patient individuals are, as expected, especially likely to report a future-oriented savings goal.

For present-biased women, future patience is a better predictor of the purpose of savings as indicated by bigger positive coefficients on the present-biased indicators when controlling for current patience (column 5) and smaller negative coefficients when controlling for future patience (columns 7), although none is statistically significant. For present-biased men, current patience is a more accurate predictor of savings goals (columns 6 and 8). In general, household heads and women are more likely to have future-oriented savings goals, as are married individuals and people with more education.

Present-biased preferences should affect how people save if they are sophisticated. In columns 9-12 of Table 6 we examine home savings as a share of total savings. We hypothesize that people with self-discipline problems are more likely to keep their money outside of the home. ${ }^{17}$ More impatient individuals save a higher proportion of their savings at

\footnotetext{
${ }^{17}$ There are 82 individuals who report not having any savings and it is not clear how to treat the share of home saving among non-savers. In Table 6 they were excluded from the sample. In order to see the bounds of how important this exclusion is, we repeated the same analysis with non-savers treated as if (1) they saved $100 \%$ at
} 
home and less outside of their household (such as in a bank, a post office, or SHG), in part because more impatient people save less overall (and saving less is associated with holding more at home). But the finding is also consistent with a higher priority placed on spending which diminishes the value of opening and using saving accounts. All else the same, presentbiased women adjust their savings practices to keep a lower proportion of their financial savings at home than the level predicted by their current discount rate (column 9): $\beta_{2}<0$.

The future discount rate is a better predictor of their saving practices (column 11). The finding is also consistent with the notion that present-biased individuals have already given in to the temptation to consume savings held at home, but then we would expect the current discount rate to be a better predictor of the share of home savings. Either interpretation yields a motivation to save through other mechanisms.

In sum, the experimentally-derived discount rates yield plausible predictions about saving behavior: patient people save more and have more "future-oriented" saving goals. Women with present-biased preferences save less than their future level of patience suggests they should. They do, though, seem aware of the tension (and thus are not fully "naïve”). The clearest evidence thus far is seen in their systematically saving less at home.

\section{Borrowing}

As noted earlier, the likelihood of borrowing rises with the level of future patience (consistent with the notion that borrowing is for investment and thus future consumption). Even after controlling for patience, the role of present-biased preferences continues to mark borrowing decisions. People with present-biased preferences borrow more, a result consistent with both the greater need for borrowing to compensate for low saving levels and for a lack of workable commitment devices. The result can be seen in simple averages: Table 5 shows that borrowing is greater for individuals with present-biased preferences, and the difference is

home and (2) they saved nothing at home. In both cases the results are qualitatively similar to those observed in Table 6. See web Appendix Table A17. 
particularly striking for women's borrowing from SHGs: 60.7 percent of women with strongly

present-biased preferences have a loan from a SHG compared to only 35.9 percent when

women are time-consistent (results for men are in web Appendix Table A4). ${ }^{18}$

In columns 1-4 of Table 7 we analyze the determinants of having a loan from any

source: from a bank, a SHG or a moneylender. As noted, patient women borrow more, a result

in keeping with the working assumption that the loans are mainly taken for business

investments and other forward-looking investments. ${ }^{19}$ For women, being married, middle-

aged, less educated, and having recently experienced a shock at the harvest increases the

likelihood of borrowing.

After controlling for other variables, strongly present-biased women are 25 percentage

points more likely to have a loan compared to the level predicted by their current discount rate

(column 1) and the coefficient on being present-biased is positive though not statistically

significant when controlling for the future discount rate (column 3).

Although for men we also observe a positive correlation between being present-biased

and having a loan, we can push the analysis further in the sample of women. First, borrowing

by men is mainly in banks, while there is substantial SHG borrowing activity among women

in our sample (42.6 percent have an SHG loan versus only 13.9 percent of men). In addition,

we didn’t find lower saving levels for present-biased men as we did for women, which

\footnotetext{
${ }^{18}$ The link between experimental choices and financial behavior could result from arbitrage behavior in which individuals make choices in the experiments predicated on their ability to borrow against the future expected income from the pay-outs. In other words, they engage in arbitrage between the lab and their outside opportunities to borrow. For example, an impatient person could choose to wait in the experiment and receive a higher expected pay-out, but then borrow outside and repay the loan after receiving the pay-out. If arbitraged perfectly, the discount rate inferred from the experimental choices should be equal to the market interest rate independently of the individual's level of patience. While theoretically possible, arbitrage is unlikely to drive our results. First, although the amounts in our experiments were relatively large, they are still well below the minimum loan size from SHGs or the formal sector. Second, arbitrage should eliminate time inconsistent choices for people with better opportunities to borrow, but a substantial proportion of individuals made time inconsistent choices in our experiments and these individuals are more likely to have a loan (and hence presumably have better access to borrowing), a result inconsistent with the arbitrage argument.

${ }^{19}$ Introductory economics tells us that patient individuals save more, and the impatient borrow more. That intuition fails, though, when we turn to the billions of people around the world, especially the poor, whose income derives largely from farming or small-scale business. As self-employed entrepreneurs, these households borrow often to support their farms and businesses.
} 
suggests that, unlike women, they have access to other ways to cope with self-discipline problems.

As in the case of saving, the result that borrowing is higher among present-biased individuals is consistent with both naïveté and sophistication. We turn next to repayment discipline and choices between different types of loans. In columns 5-8 of Table 7 the dependent variable indicates if the respondent has been delayed in repaying at least one loan installment. If the present-biased individuals were naïve, we would expect them to plan to repay but ultimately end up over-consuming and having worse repayment discipline. However, present-biased preferences do not matter in our estimates. Sophisticated present-biased individuals should, on the other hand, be more concerned about their ability to repay and hence about the type of loan they would demand. In Table 8 we study participation and borrowing from SHGs which employ structured repayment features and peer pressure. In columns 1-4 we show that women with present-biased preferences are more likely to join SHGs and we find a very close association with SHG borrowing. In columns 5-12 the dependent variable is equal to one if an individual has a loan from an SHG. We can see that the results for women's discounting and borrowing in Table 7 were largely driven by SHG loans. Strongly present-biased women are 40 percentage points more likely to borrow from SHGs than predicted by their current discount rate (column 5).

In columns 9-12, we restrict the sample to individuals who have a loan (independently of its provider) and do the same analysis. This restriction conditions on the generic demand for a loan and places the focus on loan type. After imposing the restriction, we still observe similar results for hyperbolic discounting. Conditional on borrowing, strongly present-biased women are more inclined to borrow from SHGs, which is consistent with the hypothesis that features specific to SHG contracts and practices are desirable for individuals with presentbiased preferences. (SHG loans may have other advantages with broad appeal, such as lower interest rates, but our focus here is on features that are particularly appealing to present-biased 
individuals.) When the future discount rate $\left(\delta_{i}^{1}\right)$ is included in the specification, strongly present-biased women borrow at a rate even higher than this discount rate suggests. The result is consistent with the combination of the disciplining effect of SHG loans and the desire to compensate for lower savings levels.

\section{Demand for commitment and spousal control issues}

Household conflict gives an alternative reason for why poor women may seek commitment devices and ways to structure financial plans. In this case individuals do not seek to discipline their own preferences, but try instead to “discipline” the interventions of other household members (often spouses). Anderson and Baland (2002) show that the need to protect savings from their husbands triggers women's participation in ROSCAs in a Kenyan slum. They find an "inverted-U” shaped pattern in their data: women who have little autonomy from their husbands are unlikely to join ROSCAs, as are women with great autonomy (since they do not need the protections that ROSCAs afford). Women in a middle range, though, are particularly likely to be ROSCA participants.

In all the regressions we control for a measure of women’s decision-making power within a household and its square. ${ }^{20}$ We find evidence supporting the spousal control motive for borrowing behavior, but not for savings behavior (Web appendix, Table A24-26). Women in the upper mid-range of our measure of women's position are the most likely to have a loan from SHGs. The result suggests that husbands or other family members respect women's autonomy over resources from SHG loans but less so for savings or other types of loans. The results for present-biased preferences are robust to the inclusion of these variables.

\footnotetext{
${ }^{20}$ The questions on decision-making power are taken from the Demographic and Health Surveys.
} 


\section{Conclusions}

The textbook model of optimal consumption choice abstracts from self-discipline problems that households may face, limiting their ability to save. Behavioral economics has taken selfdiscipline as a focus, centering on ways that various contracting mechanisms and types of social support can generate greater savings levels by promoting discipline. We draw a link between these kinds of disciplining mechanisms and the propensity to borrow from microcredit institutions.

The study is based on results from a series of "lab experiments in the field" designed to elicit measures of time discounting and risk aversion and survey data on financial behavior for a random sample of over 500 individuals in rural India. We show that the likelihood of borrowing from local microcredit institutions is greater for women with present-biased preferences. The finding that present-biased women favor borrowing from microcredit institutions can be partly explained by their general difficulty saving: the present-biased group is more likely to need to borrow than otherwise similar people undertaking comparable investments. But we find that when members of the present-biased group borrow, they are more likely than other (otherwise similar) borrowers to do so through microcredit institutions specifically. The finding is consistent with the notion that the structure of microcredit loans and the harnessing of social pressure provides a way to convert income flows into large sums through a device that—-for the present-biased group—is more effective than the alternative of saving up on one’s own.

It might seem that the preference for microcredit borrowing by the present-biased group reflects a giving in to the desire for current consumption (rather than being driven by the desire to accumulate). But most borrowing in our sample is for investment, and our result holds even after controlling for the baseline degree of time discounting and for the propensity to borrow in general; the time preference variable should capture aspects of loan demand associated with the desire for current consumption. 
The analysis rests on the way that microcredit loans provide discipline and peer pressure absent in the textbook lending contract. Microcredit contracts have been celebrated by economic theorists for providing novel solutions to problems of moral hazard and adverse selection. The evidence here suggests that a key to their popularity may rest as well with their role in helping borrowers discipline their financial lives. The evidence helps to explain the puzzling existence of the regular repayment schedules used in nearly all microfinance loan contracts globally (Armendáriz and Morduch 2005). The evidence also helps to explain why microcredit institutions that drop the joint liability element of group lending from their contracts nonetheless have maintained regular repayment schedules and group meetings (Xavier Giné and Dean Karlan 2008). Further research is required to quantify the roles of the specific mechanisms that aid self-discipline. 


\section{References}

Adams, William, Liran Einav, and Jonathan Levin. 2009. "Liquidity Constraints and Imperfect Information in Subprime Lending." American Economic Review, 99(1): 49-84.

Ainslie, George W. 1992. Picoeconomics. Cambridge, UK: Cambridge University Press.

Andersen, Steffen, Glenn W. Harrison, Morten I. Lau, and E. E. Rutström.

2008."Eliciting Risk and Time Preferences." Econometrica, 76(3): 583-618.

Anderson, C. L., Maya Dietz, Andrew Gordon, and Marieka Klawitter. 2004."Discount

Rates in Vietnam." Economic Development and Cultural Change, 52(4): 873-887.

Anderson, Siwan and Jean-Marie Baland. 2002."The Economics of Roscas and Intrahousehold Resource Allocation." Quarterly Journal of Economics, 117(3): 963-995.

Armendáriz De Aghion, Beatriz and Jonathan Morduch. 2005. The economics of microfinance. Cambridge, MA: MIT Press.

Ashraf, Nava, Dean Karlan, and Wesley Yin. 2006."Tying Odysseus to the Mast: Evidence from a Commitment Savings Product in the Philippines." Quarterly Journal of Economics, 121(2): 635-672.

Baland, Jean-Marie, Rohini Somanathan and Lore Vandewalle. 2008,: “”Microfinance Lifespans: A Study of Attrition and Exclusion in Self-Help Groups in India',” India Policy Forum 4: 159-210.

Barr, Abigail, and Garance Genicot. 2008. "Risk Sharing, Committment and Information: An Experimental Analysis." Journal of the European Economic Association, 6(6): 11511185. 
Basu, Karna. 2007. "A Behavioral Model of Simultaneous Borrowing and Saving." http://www.cid.harvard.edu/neudc07/docs/neudc07 s3 p07 basu.pdf.

Basu, Karna. 2008. „Hyperbolic Discounting and the Sustainability of Rotational Savings Arrangements.” http://urban.hunter.cuny.edu/ basu/research.htm

Bauer, Michal and Julie Chytilová. Forthcoming. "The Impact of Education on Subjective Discount Rate in Ugandan Villages." Economic Development and Cultural Change.

Binswanger, Hans B. 1980."Attitudes Toward Risk: Experimental Measurement in Rural India." American Journal of Agricultural Economics, 62(3): 395-407.

Cardenas, Juan C. and Jeffrey P. Carpenter. 2008. "Behavioural Development Economics: Lessons from Field Labs in the Developing World. " Journal of Development Studies, 44(3): 311-338.

Collins, Daryl, Jonathan Morduch, Stuart Rutherford and Orlanda Ruthven. 2009. Portfolios of the Poor: How the World's Poor Live on \$2 a Day. Princeton, NJ: Princeton University Press.

Consultative Group to Assist the Poor [CGAP]. 2007. "Sustainability of Self-Help Groups in India: Two Analyses." CGAP Occasional paper No. 12.

Daley-Harris, Sam. 2007. "State of the Microcredit Summit Campaign Report 2007." http://www.microcreditsummit.org/pubs/reports/socr/EngSOCR2007.pdf.

Duflo, Esther, Michael Kremer and Jonathan Robinson. 2006. "Why Don’t Farmers use Fertilizer: Evidence from Field Experiments in Western Kenya." http://www.iies.su.se/seminars/papers/070308.pdf. 
Dupas, Pascaline and Jonathan Robinson. 2009. “Savings Constraints and Microenterprise Development: Evidence from a Field Experiment in Kenya.” http://www.povertyactionlab.org/papers/90_Dupas_Savings_Constraints.pdf

Field, Erica and Rohini Pande. 2008. "Repayment Frequency and Default in Microfinance: Evidence from India." Journal of the European Economics Association, 6(2-3): 501-509.

Frederick, Shane, George Loewenstein, and Ted O'Donoghue. 2002."Time Discounting and Time Preference: A Critical Review." Journal of Economic Literature, 40(2): 351-401.

Ghatak, Maitreesh, and Timothy Guinnane. 1999. "The economics of lending with joint liability: Theory and practice.” Journal of Development Economics,60(1): 195-228.

Gine, Xavier and Dean Karlan. 2008. "Peer Monitoring and Enforcement: Long Term Evidence from Microcredit Lending Groups with and without Group Liability." http://research.yale.edu/karlan/downloads/bulak.pdf.

Gugerty, Mary K. 2007."You Can’t Save Alone: Commitment in Rotating Savings and Credit Associations in Kenya." Economic Development and Cultural Change, 55: 251-282.

Harrison, Glenn W., Morten I. Lau, and Melonie B. Williams. 2002."Estimating Individual Discount Rates in Denmark: A Field Experiment." American Economic Review, 92(5): 1606-1617.

Harrison, Glenn W. and John A. List. 2004."Field Experiments." Journal of Economic Literature, 42(4): 1009-1055.

Jensen, Robert and Emily Oster. 2007. "The Power of TV: Cable Television and Women's Status in India." http://home.uchicago.edu/ eoster/tvwomen.pdf. 
Karlan, Dean. 2005."Using Experimental Economics to Measure Social Capital and Predict Financial Decisions." American Economic Review, 95(5): 1688-1699.

Kirby, Kris N., Ricardo Godoy, Victoria Reyes-García, Elizabeth Byron, Lilian Apaza, William Leonard, Eddy Pérez, Vincent Vadez, and David Wilkie. 2002."Correlates of Delay-Discount Rates: Evidence from Tsimane' Amerindians of the Bolivian Rain Forest." Journal of Economic Psychology, 23(3): 291-316.

Knack, Stephen and Philip Keefer. 1997."Does Social Capital have an Economic Payoff? A Cross-Country Investigation." Quarterly Journal of Economics, 112(4): 1251-1288.

Kumar, Pankaj and Ramesh Golait. 2009. “Bank Penetration and SHG-Bank Linkage Programme: A Critique”. Reserve Bank of India Occasional Papers 29 (3).

Laibson, David. 1997."Golden Eggs and Hyperbolic Discounting." Quarterly Journal of Economics, 112(2): 443-477.

Lederman, Daniel, Norman V. Loayza, and Ana M. Menendez. 2002."

Violent Crime: Does Social Capital Matter?" Economic Development and Cultural Change, 50(3): 509-539.

Liu, Elaine. 2008. "Time to Change what to Sow: Risk Preferences and Technology Adoption Decisions of Cotton Farmers in China." PhD diss. Princeton University.

Meier, Stephan, and Charles Sprenger. Forthcoming. "Present-Biased Preferences and Credit Card Borrowing.” American Economic Journal: Applied Economics.

Mullainathan, Sendhil. 2005. "Development economics through the lens of psychology." In Annual wold bank conference in development economics 2005: Lessons from experience, ed. Francois Bourguignon and Boris Pleskovic, Oxford, UK: Oxford University Press. 
National Bank for Agriculture and Rural Development [NABARD]. 2007. "Snapshot of SHG-Bank Linkage in India-March 2007." NABARD report.

O'Donoghue, Ted and Matthew Rabin. 1999."Doing it Now Or Doing it Later." American Economic Review, 89(1): 103-124.

Pender, John L. 1996."Discount Rates and Credit Markets: Theory and Evidence from Rural India." Journal of Development Economics, 50(2): 257-296.

Quisumbing, Agnes R. and John A. Maluccio. 2003."Resources at Marriage and Intrahousehold Allocation: Evidence from Bangladesh, Ethiopia, Indonesia, and South Africa." Oxford Bulletin of Economics and Statistics, 65(3): 283-328.

Rutherford, Stuart. 2000. The poor and their money. USA: Oxford University Press.

Schelling, Thomas C. 1984. Choice and consequence. Cambridge, MA: Harvard University Press.

Seibel, Hans D. and Stefan Karduck. 2005. "Transaction costs of self-help groups: A study of NABARD’s SHG banking programme in india." In Financial growth in india and china. ed. Alagiri Dhandapani, Hyderabad: IFCAI Univ. Press.

Singh, Inderjit, Lyn Squire, and John Strauss. 1986. Agricultural household models: Extensions, applications, and policy. Baltimore, MD: Johns Hopkins University Press.

Strotz, Robert H. 1955."Myopia and Inconsistency in Dynamic Utility Maximization." The Review of Economic Studies, 23(3): 165-180.

Sunde, Uwe, Thomas Dohmen, Armin Falk, and David Huffman. Forthcoming. "Are Risk Aversion and Impatience Related to Cognitive Ability?" American Economic Review. 
Tanaka, Tomomi, Colin Camerer, and Quang Nguyen. Forthcoming. "Risk and Time Preferences: Experimental and Household Data from Vietnam." American Economic Review.

Thomas, Duncan. 1990."Intra-Household Resource Allocation: An Inferential Approach." Journal of Human Resources, 26(1): 635-664.

Thomas, Duncan and Amar Hamoudi. 2006. "Do You Care? Altruism and InterGenerational Exchanges in Mexico." California Center for Population Research Online Working Paper No. 008-06.

Yunus, Muhammad. 2002. "Toward eliminating poverty from the world: Grameen bank experience." In Making progress: Essays in progress and public policy, ed. C. Leigh Anderson and Janet W. Looney, Lanham: MD: Lexington Books. 
TABLE 1 -- SAMPLE CHARACTERISTICS, COMPARISON WITH KARNATAKA AVERAGES (MEANS AND STANDARD DEVIATIONS)

\begin{tabular}{|c|c|c|c|c|c|c|}
\hline & Total & Male & Female & Honavar & Haliyal & Karnataka $^{a}$ \\
\hline \multirow[t]{2}{*}{ Age (years) } & 36.822 & 38.128 & 35.496 & 36.759 & 36.885 & 36.300 \\
\hline & (11.756) & (12.091) & (11.274) & $(11.060)$ & (12.443) & \\
\hline \multirow[t]{2}{*}{ Education (classes) } & 4.256 & 5.004 & 3.496 & 5.967 & 2.519 & 4.200 \\
\hline & $(4.442)$ & (4.684) & $(4.051)$ & $(4.487)$ & (3.658) & \\
\hline \multirow[t]{2}{*}{ Illiterate } & 0.395 & 0.339 & 0.452 & 0.204 & 0.589 & 0.425 \\
\hline & $(0.489)$ & $(0.474)$ & (0.499) & $(0.404)$ & $(0.493)$ & \\
\hline \multirow[t]{2}{*}{ Married } & 0.786 & 0.796 & 0.777 & 0.729 & 0.844 & 0.670 \\
\hline & $(0.410)$ & $(0.404)$ & $(0.417)$ & $(0.445)$ & $(0.363)$ & \\
\hline \multirow[t]{2}{*}{ Farmer } & 0.702 & 0.739 & 0.664 & 0.632 & 0.772 & $0.750^{\mathrm{b}}$ \\
\hline & $(0.458)$ & $(0.440)$ & $(0.473)$ & $(0.483)$ & $(0.420)$ & \\
\hline Sample size & 544 & 274 & 270 & 274 & 270 & \\
\hline
\end{tabular}

Notes: Standard deviations in parentheses.

${ }^{\text {a }}$ Source: Indian Census 2001: data for the Karnataka population above 15

${ }^{\mathrm{b}}$ Only rural population in Karnataka

TABle 2 -- PAyoff TABle (Discount RATES)

\begin{tabular}{|c|c|c|c|c|c|}
\hline \multicolumn{3}{|c|}{ Binary choices in the current time frame } & \multicolumn{3}{|c|}{ Binary choices in the future time frame } \\
\hline & Tomorrow & $\begin{array}{l}\text { After three } \\
\text { months }\end{array}$ & & $\begin{array}{l}\text { After one } \\
\text { year }\end{array}$ & $\begin{array}{c}\text { After one year and } \\
\text { three months }\end{array}$ \\
\hline choice 1 & Rs. 250 & Rs. 265 & choice 1 & Rs. 250 & Rs. 265 \\
\hline choice 2 & Rs. 250 & Rs. 280 & choice 2 & Rs. 250 & Rs. 280 \\
\hline choice 3 & Rs. 250 & Rs. 300 & choice 3 & Rs. 250 & Rs. 300 \\
\hline choice 4 & Rs. 250 & Rs.330 & choice 4 & Rs. 250 & Rs.330 \\
\hline choice 5 & Rs. 250 & Rs. 375 & choice 5 & Rs. 250 & Rs. 375 \\
\hline
\end{tabular}


TABle 3 -- Distribution of Responses to Time Preference Questions

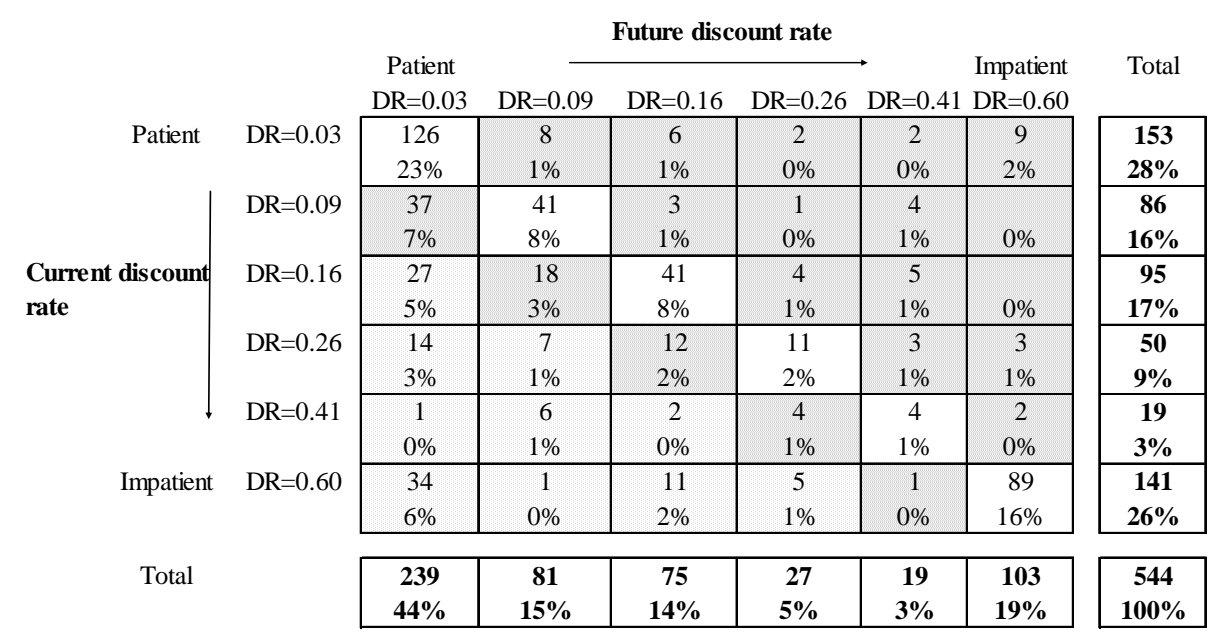

13.2\% of individuals $19.9 \%$ of individuals $9.6 \%$ of individuals
"Weakly present-biased": More patient over future tradeoffs than current tradeoffs (next to the diagonal) "Strongly present-biased": More patient over future tradeoffs than current tradeoffs (further off the diagonal) "Patient now, impatient later": Less patient over future tradeoffs than current tradeoffs 
TABLE 4 -- EXPERIMENTAL QUESTIONS AND INDIVIDUAL CHARACTERISTICS (MEANS, STANDARD DEVIATIONS)

\begin{tabular}{|c|c|c|c|c|c|c|c|c|c|c|}
\hline \multirow{3}{*}{ Dependent variable: } & \multicolumn{4}{|c|}{ Level of discounting } & \multicolumn{6}{|c|}{ Time preference reversals } \\
\hline & \multicolumn{2}{|c|}{ Current discount rate } & \multicolumn{2}{|c|}{ Future discount rate } & \multicolumn{2}{|c|}{ Strongly present-biased } & \multicolumn{2}{|c|}{ Weakly present-biased } & \multicolumn{2}{|c|}{$\begin{array}{l}\text { Patient now, impatient } \\
\text { in the future }\end{array}$} \\
\hline & $\begin{array}{l}(1) \\
\text { female }\end{array}$ & $\begin{array}{l}(2) \\
\text { male } \\
\end{array}$ & $\begin{array}{l}\text { (3) } \\
\text { female }\end{array}$ & $\begin{array}{l}4) \\
\text { male }\end{array}$ & $\begin{array}{l}\text { (5) } \\
\text { female }\end{array}$ & $\begin{array}{l}6) \\
\text { male }\end{array}$ & $\begin{array}{l}\text { (7) } \\
\text { female }\end{array}$ & $\begin{array}{l}(8) \\
\text { male } \\
\end{array}$ & $\begin{array}{l}\text { (9) } \\
\text { female }\end{array}$ & $\begin{array}{l}(10) \\
\text { male }\end{array}$ \\
\hline Gamble 2 & $\begin{array}{l}-0.035 \\
(0.058)\end{array}$ & $\begin{array}{l}0.047 \\
(0.066)\end{array}$ & $\begin{array}{l}-0.019 \\
(0.057)\end{array}$ & $\begin{array}{l}-0.057 \\
(0.067)\end{array}$ & $\begin{array}{l}0.034 \\
(0.121)\end{array}$ & $\begin{array}{l}0.283 \\
(0.222)\end{array}$ & $\begin{array}{l}-0.038 \\
(0.041)\end{array}$ & $\begin{array}{l}-0.014 \\
(0.114)\end{array}$ & $\begin{array}{l}-0.030 \\
(0.090)\end{array}$ & $\begin{array}{l}-0.029 \\
(0.075)\end{array}$ \\
\hline Gamble 3 & $\begin{array}{l}-0.054 \\
(0.050)\end{array}$ & $\begin{array}{l}0.041 \\
(0.058)\end{array}$ & $\begin{array}{l}-0.017 \\
(0.049)\end{array}$ & $\begin{array}{l}-0.026 \\
(0.059)\end{array}$ & $\begin{array}{l}-0.078 \\
(0.085)\end{array}$ & $\begin{array}{l}0.200 \\
(0.185)\end{array}$ & $\begin{array}{l}-0.090 \\
(0.036)^{* *}\end{array}$ & $\begin{array}{l}0.111 \\
(0.138)\end{array}$ & $\begin{array}{l}0.032 \\
(0.111)\end{array}$ & $\begin{array}{l}0.054 \\
(0.095)\end{array}$ \\
\hline Gamble 4 & $\begin{array}{l}-0.159 \\
(0.054)^{* * *}\end{array}$ & $\begin{array}{l}0.029 \\
(0.063)\end{array}$ & $\begin{array}{l}-0.085 \\
(0.052)\end{array}$ & $\begin{array}{l}-0.039 \\
(0.064)\end{array}$ & $\begin{array}{l}-0.082 \\
(0.083)\end{array}$ & $\begin{array}{l}0.137 \\
(0.189)\end{array}$ & $\begin{array}{l}-0.046 \\
(0.039)\end{array}$ & $\begin{array}{l}0.228 \\
(0.189)\end{array}$ & $\begin{array}{l}0.135 \\
(0.151)\end{array}$ & $\begin{array}{l}-0.004 \\
(0.081)\end{array}$ \\
\hline Gamble 5 & $\begin{array}{l}-0.084 \\
(0.054)\end{array}$ & $\begin{array}{l}0.021 \\
(0.059)\end{array}$ & $\begin{array}{l}-0.047 \\
(0.053)\end{array}$ & $\begin{array}{l}-0.020 \\
(0.060)\end{array}$ & $\begin{array}{l}-0.079 \\
(0.084)\end{array}$ & $\begin{array}{l}0.258 \\
(0.200)\end{array}$ & $\begin{array}{l}-0.067 \\
(0.032)\end{array}$ & $\begin{array}{l}0.095 \\
(0.134)\end{array}$ & $\begin{array}{l}0.025 \\
(0.115)\end{array}$ & $\begin{array}{l}0.079 \\
(0.106)\end{array}$ \\
\hline Gamble 6 & $\begin{array}{l}-0.097 \\
(0.056)^{*}\end{array}$ & $\begin{array}{l}0.029 \\
(0.058)\end{array}$ & $\begin{array}{l}-0.060 \\
(0.054)\end{array}$ & $\begin{array}{l}-0.042 \\
(0.059)\end{array}$ & $\begin{array}{l}-0.126 \\
(0.072)\end{array}$ & $\begin{array}{l}0.214 \\
(0.190)\end{array}$ & $\begin{array}{l}0.006 \\
(0.066)\end{array}$ & $\begin{array}{l}0.121 \\
(0.140)\end{array}$ & $\begin{array}{l}-0.109 \\
(0.060)\end{array}$ & $\begin{array}{l}0.048 \\
(0.092)\end{array}$ \\
\hline Education & $\begin{array}{l}-0.003 \\
(0.004)\end{array}$ & $\begin{array}{l}-0.012 \\
(0.005)^{* *}\end{array}$ & $\begin{array}{l}-0.005 \\
(0.004)\end{array}$ & $\begin{array}{l}-0.020 \\
(0.005)^{* * *}\end{array}$ & $\begin{array}{l}-0.005 \\
(0.009)\end{array}$ & $\begin{array}{l}0.003 \\
(0.009)\end{array}$ & $\begin{array}{l}0.000 \\
(0.005)\end{array}$ & $\begin{array}{l}0.003 \\
(0.008)\end{array}$ & $\begin{array}{l}-0.009 \\
(0.010)\end{array}$ & $\begin{array}{l}-0.009 \\
(0.007)\end{array}$ \\
\hline Age & $\begin{array}{l}0.003 \\
(0.008)\end{array}$ & $\begin{array}{l}-0.008 \\
(0.010)\end{array}$ & $\begin{array}{l}0.002 \\
(0.008)\end{array}$ & $\begin{array}{l}-0.016 \\
(0.010)\end{array}$ & $\begin{array}{l}-0.017 \\
(0.016)\end{array}$ & $\begin{array}{l}0.006 \\
(0.018)\end{array}$ & $\begin{array}{l}0.003 \\
(0.011)\end{array}$ & $\begin{array}{l}0.015 \\
(0.016)\end{array}$ & $\begin{array}{l}-0.011 \\
(0.019)\end{array}$ & $\begin{array}{l}0.005 \\
(0.015)\end{array}$ \\
\hline$(\text { Age })^{2}$ & $\begin{array}{l}-0.000 \\
(0.000)\end{array}$ & $\begin{array}{l}0.000 \\
(0.000)\end{array}$ & $\begin{array}{l}-0.000 \\
(0.000)\end{array}$ & $\begin{array}{l}0.000 \\
(0.000)\end{array}$ & $\begin{array}{l}0.000 \\
(0.000)\end{array}$ & $\begin{array}{l}-0.000 \\
(0.000)\end{array}$ & $\begin{array}{l}-0.000 \\
(0.000)\end{array}$ & $\begin{array}{l}-0.000 \\
(0.000)\end{array}$ & $\begin{array}{l}0.000 \\
(0.000)\end{array}$ & $\begin{array}{l}-0.000 \\
(0.000)\end{array}$ \\
\hline Married & $\begin{array}{l}0.026 \\
(0.044)\end{array}$ & $\begin{array}{l}-0.003 \\
(0.060)\end{array}$ & $\begin{array}{l}0.013 \\
(0.043)\end{array}$ & $\begin{array}{l}0.079 \\
(0.061)\end{array}$ & $\begin{array}{l}0.099 \\
(0.072)\end{array}$ & $\begin{array}{l}-0.137 \\
(0.139)\end{array}$ & $\begin{array}{l}-0.043 \\
(0.073)\end{array}$ & $\begin{array}{l}-0.053 \\
(0.112)\end{array}$ & & $\begin{array}{l}-0.103 \\
(0.115)\end{array}$ \\
\hline Household head & $\begin{array}{l}-0.015 \\
(0.056)\end{array}$ & $\begin{array}{l}-0.019 \\
(0.045)\end{array}$ & $\begin{array}{l}-0.036 \\
(0.055)\end{array}$ & $\begin{array}{l}-0.024 \\
(0.046)\end{array}$ & $\begin{array}{l}0.229 \\
(0.167)\end{array}$ & $\begin{array}{l}0.045 \\
(0.082)\end{array}$ & $\begin{array}{l}-0.002 \\
(0.072)\end{array}$ & $\begin{array}{l}-0.061 \\
(0.081)\end{array}$ & & $\begin{array}{l}0.070 \\
(0.050)\end{array}$ \\
\hline Wealth & $\begin{array}{l}0.011 \\
(0.008)\end{array}$ & $\begin{array}{l}0.004 \\
(0.009)\end{array}$ & $\begin{array}{l}0.008 \\
(0.008)\end{array}$ & $\begin{array}{l}0.006 \\
(0.010)\end{array}$ & $\begin{array}{l}-0.006 \\
(0.017)\end{array}$ & $\begin{array}{l}-0.013 \\
(0.018)\end{array}$ & $\begin{array}{l}-0.005 \\
(0.011)\end{array}$ & $\begin{array}{l}0.022 \\
(0.014)\end{array}$ & $\begin{array}{l}-0.036 \\
(0.023)\end{array}$ & $\begin{array}{l}0.001 \\
(0.014)\end{array}$ \\
\hline Relative income & $\begin{array}{l}0.009 \\
(0.027)\end{array}$ & $\begin{array}{l}-0.034 \\
(0.030)\end{array}$ & $\begin{array}{l}-0.009 \\
(0.026)\end{array}$ & $\begin{array}{l}-0.054 \\
(0.031)^{*}\end{array}$ & $\begin{array}{l}0.015 \\
(0.054)\end{array}$ & $\begin{array}{l}-0.037 \\
(0.055)\end{array}$ & $\begin{array}{l}0.035 \\
(0.038)\end{array}$ & $\begin{array}{l}0.067 \\
(0.049)\end{array}$ & $\begin{array}{l}-0.025 \\
(0.054)\end{array}$ & $\begin{array}{l}-0.075 \\
(0.041)^{*}\end{array}$ \\
\hline Farmer & $\begin{array}{l}0.028 \\
(0.031)\end{array}$ & $\begin{array}{l}-0.021 \\
(0.039)\end{array}$ & $\begin{array}{l}-0.010 \\
(0.030)\end{array}$ & $\begin{array}{l}-0.037 \\
(0.040)\end{array}$ & $\begin{array}{l}0.097 \\
(0.056)\end{array}$ & $\begin{array}{l}0.119 \\
(0.059)^{*}\end{array}$ & $\begin{array}{l}-0.082 \\
(0.055)\end{array}$ & $\begin{array}{l}-0.105 \\
(0.080)\end{array}$ & $\begin{array}{l}-0.176 \\
(0.098)^{*}\end{array}$ & $\begin{array}{l}0.022 \\
(0.045)\end{array}$ \\
\hline Negative shock from harvest & $\begin{array}{l}-0.036 \\
(0.029)\end{array}$ & $\begin{array}{l}-0.005 \\
(0.035)\end{array}$ & $\begin{array}{l}0.010 \\
(0.029)\end{array}$ & $\begin{array}{l}0.010 \\
(0.036)\end{array}$ & $\begin{array}{l}-0.090 \\
(0.056)\end{array}$ & $\begin{array}{l}-0.090 \\
(0.067)\end{array}$ & $\begin{array}{l}0.046 \\
(0.047)\end{array}$ & $\begin{array}{l}0.094 \\
(0.056)^{*}\end{array}$ & $\begin{array}{l}-0.022 \\
(0.061)\end{array}$ & $\begin{array}{l}0.029 \\
(0.050)\end{array}$ \\
\hline Observations & 266 & 272 & 266 & 272 & 266 & 243 & 211 & 216 & 151 & 244 \\
\hline (Pseudo) R-squared & 0.29 & 0.24 & 0.20 & 0.22 & 0.16 & 0.12 & 0.22 & 0.16 & 0.19 & 0.13 \\
\hline
\end{tabular}

Notes: All specifications include village fixed effects. OLS in columns 1-4. Probit, marginal effects reported in columns 5-10. In columns 1-2 the dependent variable is the "Current discount rate" calculated from the binary choices between amount next day and amount after three months. It has six values calculated as arithmetic means of inferred ranges of discount rate. In columns 3-4 the dependent variable is the "Future discount rate" calculated from the binary choices between amount after one year or amount after one year and three months. In column 5,6 the dependent variable "Strongly present-biased preferences" equals to one if the respondent chose the more delayed reward two or more binary choices later in the current time frame than in the future time frame.

In columns 7,8 the dependent variable "Weakly present-biased preferences" equals to one if the respondent chose the more delayed reward one binary choice later in the current time frame than in the future time frame. In columns 9,10 the dependent variable "Patient now, impatient in the future" equals to one if the respondent chose more delayed reward earlier in the current time frame than in the future time frame. Omitted dummy variable for risk aversion is "Gamble 1" (the most risk averse choice). In Column 9 the variables "Married" and "Household head" dropped due to lack of variation.

* significant at $10 \%$

** significant at $5 \%$

$* * *$ significant at $1 \%$ 
TABle 5 -- Time Discounting And Financial Behavior of Women (MEAns and Standard Deviations)

\begin{tabular}{|c|c|c|c|c|c|c|c|}
\hline & \multirow[t]{2}{*}{ All women } & \multicolumn{2}{|c|}{ Future discount rate } & \multicolumn{4}{|c|}{ Time consistency } \\
\hline & & Low & High & $\begin{array}{c}\text { Strongly } \\
\text { present-biased }\end{array}$ & $\begin{array}{c}\text { Weakly } \\
\text { present- } \\
\text { biased }\end{array}$ & $\begin{array}{c}\text { Time } \\
\text { consistent }\end{array}$ & $\begin{array}{l}\text { Patient now, } \\
\text { impatient in } \\
\text { future }\end{array}$ \\
\hline \multicolumn{8}{|l|}{ Borrowing } \\
\hline \multirow[t]{2}{*}{ Loan (dummy) } & 0.641 & 0.688 & 0.557 & 0.768 & 0.632 & 0.621 & 0.478 \\
\hline & $(0.481)$ & $(0.465)^{\mathrm{c}}$ & $(0.499)^{\mathrm{C}}$ & $(0.426)^{\mathrm{d}}$ & $(0.489)$ & $(0.487)$ & $(0.511)$ \\
\hline \multirow[t]{2}{*}{ SHG loan (dummy) } & 0.426 & 0.457 & 0.371 & 0.607 & 0.447 & 0.359 & 0.391 \\
\hline & $(0.495)$ & $(0.500)$ & $(0.486)$ & $(0.493)^{\mathrm{d}}$ & $(0.504)$ & $(0.481)$ & (0.499) \\
\hline \multirow[t]{2}{*}{ SHG loan (dummy) ${ }^{\mathrm{a}}$} & 0.665 & 0.664 & 0.667 & 0.791 & 0.708 & 0.579 & 0.818 \\
\hline & $(0.473)$ & $(0.474)$ & $(0.476)$ & $(0.412)^{d}$ & $(0.464)$ & $(0.496)$ & $(0.405)$ \\
\hline \multicolumn{8}{|l|}{ Saving } \\
\hline \multirow[t]{2}{*}{ Any savings (dummy) } & 0.863 & 0.884 & 0.825 & 0.857 & 0.842 & 0.876 & 0.826 \\
\hline & $(0.345)$ & $(0.321)$ & $(0.382)$ & $(0.353)$ & $(0.370)$ & $(0.331)$ & $(0.388)$ \\
\hline \multirow[t]{2}{*}{ Total savings (Rs. th.) } & 2.016 & 2.198 & 1.691 & 1.636 & 2.069 & 2.305 & 0.936 \\
\hline & (2.736) & $(2.646)$ & $(2.875)$ & (1.788) & (3.808) & (2.849) & $(0.952)^{\mathrm{d}}$ \\
\hline \multirow[t]{2}{*}{ Share of home savings (\%) } & 0.191 & 0.182 & 0.208 & 0.164 & 0.148 & 0.194 & 0.306 \\
\hline & $(0.303)$ & $(0.291)$ & $(0.326)$ & $(0.278)$ & $(0.260)$ & $(0.307)$ & $(0.388)$ \\
\hline \multirow[t]{2}{*}{ Future-oriented purpose of savings (dummy) } & 0.591 & 0.680 & 0.433 & 0.589 & 0.632 & 0.579 & 0.609 \\
\hline & $(0.493)$ & $(0.468)^{\mathrm{C}}$ & $(0.498)^{c}$ & $(0.496)$ & $(0.489)$ & $(0.495)$ & $(0.499)$ \\
\hline
\end{tabular}

Notes: The variable "Loan" equals to one, if an individual has an outstanding loan from a bank, Self-help group (SHG), NGO or moneylender. The variable "SHG loan" equals to one, if an individual has an outstanding loan from SHG. The variable "Any savings" equals to one if a respondent reports any financial savings. "Total savings (in thousands of Rs.)" are calculated as a sum of savings on a bank account, in a post office, contributions to SHGs and financial savings held at home. "Share of home savings" is equal to financial home savings divided by "Total savings". "Future-oriented purpose of savings" is equal to one, if the major self-reported purpose of savings is future-oriented (agricultural investment, business, education, doctor), and equal to zero, if it focuses on current consumption (celebration, personal items, household equipment).

a The sample is restricted to only those who have any outstanding loan ("Loan"=1).

${ }^{\mathrm{b}}$ The sample is restricted to only those who report having financial savings ("Any savings"=1).

${ }^{\mathrm{c}}$ Difference significant at $5 \%$ level (t-test), comparison of groups below and above median future patience

${ }^{\mathrm{d}}$ Difference significant at $5 \%$ level (t-test), comparison with time consistent group 
TABLE 6 -- Time INCONSISTENT PREFERENCES AND SAVING

\begin{tabular}{|c|c|c|c|c|c|c|c|c|c|c|c|c|}
\hline \multirow{3}{*}{$\begin{array}{l}\text { Estimator } \\
\text { Dependent variable: } \\
\text { Conditioned by: }\end{array}$} & \multicolumn{4}{|c|}{$\begin{array}{c}\text { OLS } \\
\text { Total savings (Rs. th.) }\end{array}$} & \multicolumn{4}{|c|}{$\begin{array}{c}\text { Probit } \\
\text { Future-oriented purpose of savings }\end{array}$} & \multicolumn{4}{|c|}{$\begin{array}{c}\text { Tobit } \\
\text { Share of home savings }^{\mathrm{a}} \\
\end{array}$} \\
\hline & \multicolumn{2}{|c|}{ Current discount rate } & \multicolumn{2}{|c|}{$\underline{\text { Future discount rate }}$} & \multicolumn{2}{|c|}{ Current discount rate } & \multicolumn{2}{|c|}{ Future discount rate } & \multicolumn{2}{|c|}{ Current discount rate } & \multicolumn{2}{|c|}{ Future discount rate } \\
\hline & $\begin{array}{l}1) \\
\text { female }\end{array}$ & $\begin{array}{l}(2) \\
\text { male }\end{array}$ & $\begin{array}{l}(3) \\
\text { female }\end{array}$ & $\begin{array}{l}(4) \\
\text { male }\end{array}$ & $\begin{array}{l}5) \\
\text { female }\end{array}$ & $\begin{array}{l}(6) \\
\text { male }\end{array}$ & $\begin{array}{l}(7) \\
\text { female }\end{array}$ & $\begin{array}{l}8) \\
\text { male }\end{array}$ & $\begin{array}{l}9) \\
\text { female }\end{array}$ & $\begin{array}{l}(10) \\
\text { male }\end{array}$ & $\begin{array}{l}(11) \\
\text { female }\end{array}$ & $\begin{array}{l}(12) \\
\text { male }\end{array}$ \\
\hline Strongly present-biased & $\begin{array}{l}-0.277 \\
(0.450)\end{array}$ & $\begin{array}{l}0.641 \\
(1.123)\end{array}$ & $\begin{array}{l}-0.839 \\
(0.442)^{*}\end{array}$ & $\begin{array}{l}0.059 \\
(1.189)\end{array}$ & $\begin{array}{l}0.116 \\
(0.097)\end{array}$ & $\begin{array}{l}-0.022 \\
(0.103)\end{array}$ & $\begin{array}{l}-0.039 \\
(0.105)\end{array}$ & $\begin{array}{l}-0.197 \\
(0.101)^{*}\end{array}$ & $\begin{array}{l}-0.179 \\
(0.089)^{* *}\end{array}$ & $\begin{array}{l}-0.132 \\
(0.125)\end{array}$ & $\begin{array}{l}0.015 \\
(0.083)\end{array}$ & $\begin{array}{l}-0.034 \\
(0.126)\end{array}$ \\
\hline Weakly present-biased & $\begin{array}{l}-0.202 \\
(0.535)\end{array}$ & $\begin{array}{l}-0.634 \\
(1.321)\end{array}$ & $\begin{array}{l}-0.363 \\
(0.535)\end{array}$ & $\begin{array}{l}-1.003 \\
(1.351)\end{array}$ & $\begin{array}{l}0.025 \\
(0.125)\end{array}$ & $\begin{array}{l}0.099 \\
(0.117)\end{array}$ & $\begin{array}{l}-0.015 \\
(0.130)\end{array}$ & $\begin{array}{l}0.076 \\
(0.120)\end{array}$ & $\begin{array}{l}0.037 \\
(0.101)\end{array}$ & $\begin{array}{l}-0.044 \\
(0.144)\end{array}$ & $\begin{array}{l}0.095 \\
(0.101)\end{array}$ & $\begin{array}{l}-0.008 \\
(0.146)\end{array}$ \\
\hline Current discount rate & $\begin{array}{l}-1.438 \\
(0.920)\end{array}$ & $\begin{array}{l}-0.462 \\
(2.041)\end{array}$ & & & $\begin{array}{l}-0.462 \\
(0.206)^{* *}\end{array}$ & $\begin{array}{l}-0.520 \\
(0.186)^{* * *}\end{array}$ & & & $\begin{array}{l}0.603 \\
(0.167)^{* * *}\end{array}$ & $\begin{array}{l}0.181 \\
(0.225)\end{array}$ & & \\
\hline Future discount rate & & & $\begin{array}{l}-2.032 \\
(0.952)^{* *}\end{array}$ & $\begin{array}{l}-2.294 \\
(2.109)\end{array}$ & & & $\begin{array}{l}-0.460 \\
(0.216)^{* *}\end{array}$ & $\begin{array}{l}-0.486 \\
(0.195) * *\end{array}$ & & & $\begin{array}{l}0.500 \\
(0.176) * * *\end{array}$ & $\begin{array}{l}0.358 \\
(0.228)\end{array}$ \\
\hline Patient now, impatient in future & $\begin{array}{l}-1.279 \\
(0.605)^{* *}\end{array}$ & $\begin{array}{l}-0.257 \\
(1.402)\end{array}$ & $\begin{array}{l}-0.892 \\
(0.611)\end{array}$ & $\begin{array}{l}0.144 \\
(1.377)\end{array}$ & $\begin{array}{l}-0.027 \\
(0.138)\end{array}$ & $\begin{array}{l}0.124 \\
(0.131)\end{array}$ & $\begin{array}{l}0.072 \\
(0.130)\end{array}$ & $\begin{array}{l}0.268 \\
(0.112)^{* *}\end{array}$ & $\begin{array}{l}0.230 \\
(0.107)^{* *}\end{array}$ & $\begin{array}{l}0.102 \\
(0.150)\end{array}$ & $\begin{array}{l}0.109 \\
(0.111)\end{array}$ & $\begin{array}{l}0.016 \\
(0.150)\end{array}$ \\
\hline (Pseudo) R-squared & 0.26 & 0.33 & 0.26 & 0.33 & 0.29 & 0.26 & 0.29 & 0.25 & 0.35 & 0.16 & 0.34 & 0.16 \\
\hline Number of observations & 249 & 272 & 249 & 272 & 248 & 271 & 248 & 271 & 213 & 227 & 213 & 227 \\
\hline
\end{tabular}

Notes: In all specifications we control for risk aversion (six dummies corresponding to chosen gamble), observable characteristics (education, age, married, household head, wealth, relative income, farmer, negative shock from harvest; for women we also control for their position within household) and village fixed effects. The dependent variable in columns 1-4 are "Total savings (in thousands of Rs.)" and it is calculated as a sum of savings on a bank account, in a post office, contributions to SHGs and financial savings held at home. The dependent variable in columns 5-8 is "Share of home savings" and it is equal to financial home savings divided by "Total savings". The dependent variable in columns 9-12 "Futureoriented purpose of savings" is equal to ome, if the major self-reported purpose of savings is future-oriented (agricultural investment, business, education, doctor), and equal to zero, if it focuses on current consumption (celebration, personal items, household equipment).

${ }^{\mathrm{a}}$ The sample is restricted to only those who report having positive financial savings ("Total savings">0)

* significant at $10 \%$

** significant at $5 \%$

$* * *$ significant at $1 \%$ 
TABLE 7 -- TIME INCONSISTENT PREFERENCES AND BORROWING

\begin{tabular}{|c|c|c|c|c|c|c|c|c|}
\hline \multirow{5}{*}{$\begin{array}{l}\text { Estimator } \\
\text { Dependent variable: } \\
\text { Conditioned by: }\end{array}$} & \multirow{2}{*}{\multicolumn{4}{|c|}{$\begin{array}{c}\text { Probit } \\
\text { Loan } \\
\end{array}$}} & \multicolumn{4}{|c|}{ Probit } \\
\hline & & & & & \multicolumn{4}{|c|}{ Delayed repayment of outstanding loan ${ }^{\mathrm{a}}$} \\
\hline & \multicolumn{2}{|c|}{ Current discount rate } & \multicolumn{2}{|c|}{ Future discount rate } & \multicolumn{2}{|c|}{ Current discount rate } & \multicolumn{2}{|c|}{ Future discount rate } \\
\hline & (1) & (2) & (3) & (4) & (5) & (6) & (7) & (8) \\
\hline & female & male & female & male & female & male & female & male \\
\hline \multirow[t]{2}{*}{ Strongly present-biased } & 0.246 & 0.179 & 0.112 & 0.230 & 0.060 & 0.088 & -0.064 & 0.111 \\
\hline & $(0.085)^{* *}$ & $(0.091)^{*}$ & $(0.100)$ & $(0.090)^{* *}$ & $(0.140)$ & $(0.116)$ & $(0.150)$ & $(0.125)$ \\
\hline \multirow[t]{2}{*}{ Weakly present-biased } & -0.019 & 0.118 & -0.059 & 0.154 & -0.048 & 0.139 & -0.099 & 0.138 \\
\hline & $(0.120)$ & $(0.106)$ & $(0.124)$ & $(0.104)$ & $(0.190)$ & $(0.140)$ & $(0.191)$ & $(0.143)$ \\
\hline \multirow[t]{2}{*}{ Current discount rate } & -0.426 & 0.031 & & & -0.424 & 0.113 & & \\
\hline & $(0.219)^{*}$ & $(0.180)$ & & & $(0.338)$ & $(0.233)$ & & \\
\hline \multirow[t]{2}{*}{ Future discount rate } & & & -0.582 & 0.243 & & & -0.380 & 0.073 \\
\hline & & & $(0.221)^{* * *}$ & $(0.187)$ & & & $(0.401)$ & $(0.242)$ \\
\hline \multirow[t]{2}{*}{ Patient now, impatient in future } & -0.208 & -0.018 & -0.096 & -0.058 & 0.257 & 0.090 & 0.275 & 0.062 \\
\hline & $(0.136)$ & $(0.126)$ & $(0.138)$ & $(0.126)$ & $(0.130)$ & $(0.169)$ & $(0.119)$ & $(0.177)$ \\
\hline Pseudo R-squared & 0.30 & 0.24 & 0.31 & 0.24 & 0.33 & 0.18 & 0.33 & 018 \\
\hline Number of observations & 241 & 272 & 272 & 241 & 130 & 151 & 130 & 151 \\
\hline
\end{tabular}

Notes: In all specifications we control for risk aversion (six dummies corresponding to chosen gamble), observable characteristics

(education, age, married, household head, wealth, relative income, farmer, negative shock from harvest; for women we also control for their position within household) and village fixed effects. The dependent variable in columns 1-4 is "Loan" and it equals to one, if an individual has an outstanding loan from a bank, self-help group (SHG), NGO or moneylender. The dependent variable in columns 5-8 is "Delayed

repayment of outstanding loan" and it equals to one if the respondent reports being delayed on repayment of the outstanding loan for at least one installment.

a The sample is restricted to only those who have any outstanding loans ("Loan"=1)

* significant at $10 \%$

** significant at $5 \%$

$* * *$ significant at $1 \%$ 
TABLE 8 -- Time InCONSISTENT PREFERENCES AND SHG BORROWING

\begin{tabular}{|c|c|c|c|c|c|c|c|c|c|c|c|c|}
\hline \multirow{4}{*}{$\begin{array}{l}\text { Estimator } \\
\text { Dependent variable: } \\
\text { Conditioned by: }\end{array}$} & \multicolumn{4}{|c|}{$\begin{array}{c}\text { Probit } \\
\text { SHG participation }\end{array}$} & \multicolumn{4}{|c|}{$\begin{array}{c}\text { Probit } \\
\text { SHGborrowing }\end{array}$} & \multicolumn{4}{|c|}{$\begin{array}{c}\text { Probit } \\
\text { HG borrowing }^{\mathrm{a}} \\
\end{array}$} \\
\hline & \multicolumn{2}{|c|}{ Current discount rate } & \multicolumn{2}{|c|}{ Future discount rate } & \multicolumn{2}{|c|}{ Current discount rate } & \multicolumn{2}{|c|}{ Future discount rate } & \multicolumn{2}{|c|}{ Current discount rate } & \multicolumn{2}{|c|}{ Future discount rate } \\
\hline & (1) & (2) & (3) & (4) & (5) & (6) & (7) & (8) & (9) & (10) & (11) & (12) \\
\hline & female & male & female & male & female & male & female & male & female & male & female & male \\
\hline \multirow[t]{2}{*}{ Strongly present-biased } & 0.277 & 0.076 & -0.009 & 0.062 & 0.401 & 0.052 & 0.216 & 0.024 & 0.318 & 0.011 & 0.253 & -0.040 \\
\hline & $(0.073)^{* * *}$ & $(0.080)$ & $(0.109)$ & $(0.082)$ & $(0.098)^{* * *}$ & $(0.050)$ & $(0.107)^{* *}$ & $(0.044)$ & $(0.080)^{* * *}$ & $(0.088)$ & $(0.093)^{* *}$ & $(0.084)$ \\
\hline \multirow[t]{2}{*}{ Weakly present-biased } & -0.046 & -0.058 & -0.136 & -0.048 & 0.050 & -0.061 & -0.009 & -0.062 & 0.014 & -0.180 & -0.021 & -0.184 \\
\hline & $(0.125)$ & $(0.067)$ & $(0.133)$ & $(0.072)$ & $(0.130)$ & $(0.022) *$ & $(0.128)$ & $(0.022)^{*}$ & $(0.161)$ & $(0.046)^{* * *}$ & $(0.167)$ & $(0.051)^{* *}$ \\
\hline \multirow[t]{2}{*}{ Current discount rate } & -0.911 & -0.113 & & & -0.514 & -0.083 & & & -0.303 & -0.190 & & \\
\hline & $(0.239) * * *$ & $(0.122)$ & & & $(0.252)^{* *}$ & $(0.063)$ & & & $(0.328)$ & $(0.154)$ & & \\
\hline \multirow[t]{2}{*}{ Future discount rate } & & & -1.110 & 0.013 & & & -0.738 & -0.040 & & & -0.375 & -0.146 \\
\hline & & & $(0.253)^{* * *}$ & $(0.128)$ & & & $(0.272)^{* * *}$ & $(0.069)$ & & & $(0.366)$ & $(0.165)$ \\
\hline \multirow[t]{2}{*}{ Patient now, impatient in future } & -0.075 & -0.088 & 0.132 & -0.075 & 0.051 & -0.053 & 0.180 & -0.045 & 0.225 & -0.129 & 0.238 & -0.107 \\
\hline & $(0.140)$ & $(0.065)$ & $(0.109)$ & $(0.069)$ & $(0.152)$ & $(0.025)$ & $(0.155)$ & $(0.030)$ & $(0.092)$ & $(0.055)$ & $(0.081)$ & $(0.074)$ \\
\hline Conditional on borrowing? & no & no & no & no & no & no & no & no & yes & yes & yes & yes \\
\hline Pseudo R-squared & 0.35 & 0.21 & 0.38 & 0.20 & 0.28 & 0.19 & 0.29 & 0.19 & 0.32 & 0.27 & 0.32 & 0.26 \\
\hline Observations & 239 & 261 & 239 & 261 & 232 & 250 & 232 & 250 & 139 & 140 & 139 & 140 \\
\hline
\end{tabular}

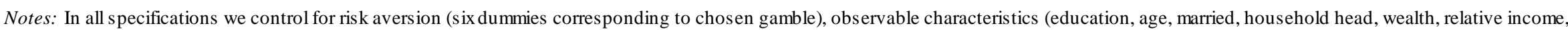
farmer, negative shock from harvest; for women we also control for their position within household) and village fixed effects. The dependent variable in columns 1-4 is "SHG participation" and it

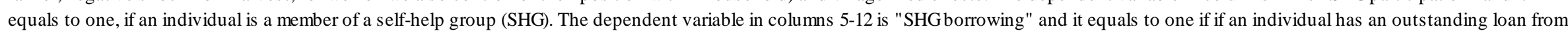
a self-help group (SHG). In columns 9-12 only those who borrow are included.

a The sample is restricted to only those who have any outstanding loans ("Loan"=1)

* significant at $10 \%$

** significant at $5 \%$

$* * *$ significant at $1 \%$ 


\section{Appendix A}

TABLE A1 -- DEFINITION OF VARIABLES

\begin{tabular}{|c|c|c|c|}
\hline Variables & Definition & Mean & Std dev \\
\hline \multicolumn{4}{|l|}{ Experimental choices } \\
\hline Current discount rate & $\begin{array}{l}6 \text { values approximating } 3 \text {-months discount rate in earlier time frame: } \\
0.03=\text { if discount rate }<6 \% ; 0.09=\text { if } 6 \%<\text { discount rate }<12 \% ; 0.16 \text { if } 12 \% \\
<\text { discount rate }<20 \% ; 0.26=\text { if } 20 \%<\text { discount rate }<32 \%, 0.14 \text { if } 32 \%< \\
\text { discount rate }<50 \% \text {; } 0.6=\text { if } 50 \%<\text { discount rate }\end{array}$ & 0.244 & 0.228 \\
\hline Future discount rate & $\begin{array}{l}6 \text { values approximating } 3 \text {-months discount rate in delayed time frame: } \\
0.03=\text { if discount rate }<6 \% ; 0.09=\text { if } 6 \%<\text { discount rate }<12 \% ; 0.16 \text { if } 12 \% \\
<\text { discount rate }<20 \% ; 0.26=\text { if } 20 \%<\text { discount rate }<32 \%, 0.14 \text { if } 32 \%< \\
\text { discount rate }<50 \% \text {; } 0.6=\text { if } 50 \%<\text { discount rate }\end{array}$ & 0.193 & 0.221 \\
\hline Strongly present-biased & $\begin{array}{l}\text { dummy; } 1=\text { current discount rate }>>\text { future discount rate, the future income } \\
\text { option is chosen at least two rows later in the current time frame than in the } \\
\text { future time frame }\end{array}$ & 0.199 & 0.399 \\
\hline Weakly present-biased & $\begin{array}{l}\text { dummy; } 1=\text { current discount rate }>\text { future discount rate, the future income } \\
\text { option is chosen one row later in the current time frame than in the future } \\
\text { time frame }\end{array}$ & 0.132 & 0.339 \\
\hline Patient now, impatient in the future & dummy, $1=$ current discount rate $<$ future discount rate & 0.096 & 0.294 \\
\hline Attitude to risk & $\begin{array}{l}\text { set of dummies, one for each of the following gambles: }(250,250) ;(225,475) \text {; } \\
(200,600) ;(150,750) ;(50,950) ;(0,1000)\end{array}$ & & \\
\hline \multicolumn{4}{|l|}{ Financial behavior } \\
\hline Loan & Dummy; 1 = has an outstanding loan; $0=$ doesn't have an outstanding loan & 0.597 & 0.491 \\
\hline Delayed repayment of outstanding loan & $\begin{array}{l}\text { Dummy; } 1 \text { = being delayed on repayment of the outstanding loan for at } \\
\text { least one installment; } 0=\text { never delayed on repayment }\end{array}$ & 0.628 & 0.484 \\
\hline SHG participation & $\begin{array}{l}\text { Dummy; } 1 \text { = being a member of a self-help group (SHG); } 0 \text { = not being a } \\
\text { member of a SHG }\end{array}$ & & \\
\hline SHGloan & $\begin{array}{l}\text { Dummy; } 1 \text { = has an outstanding loan from SHG; } 0=\text { doesn't have an } \\
\text { outstanding loan from SHG }\end{array}$ & 0.281 & 0.450 \\
\hline Total savings & $\begin{array}{l}\text { Rs. th. (savings in bank }+ \text { savings in post office }+ \text { SHG monthly } \\
\text { contribution*average length of participation + home savings) }\end{array}$ & 2.569 & 5.454 \\
\hline Share of home savings & Home savings /Total savings (\%, only those who save) & 0.333 & 0.386 \\
\hline Future oriented purpose of savings & $\begin{array}{l}\text { Dummy; } 1=\text { if the major purpose of savings is future-oriented (agricultural } \\
\text { investment, business, education, doctor); } 0=\text { if it focuses on current } \\
\text { consumption (celebration, personal items, household equipment) }\end{array}$ & 0.546 & 0.498 \\
\hline \multicolumn{4}{|l|}{ Socioeconomic characteristics } \\
\hline Female & Dummy; 1 = female; 0 = male & 0.496 & 0.500 \\
\hline Age & Age in years & 36.822 & 11.756 \\
\hline Education & Years of schooling completed & 4.256 & 4.442 \\
\hline Married & Dummy; $1=$ married; $0=$ single or widow & 0.786 & 0.410 \\
\hline Household head & Dummy; 1 = household head; 0 = non household head & 0.397 & 0.490 \\
\hline Wealth index & $\begin{array}{l}\text { Wealth index calculated by principal component analyses from questions } \\
\text { on type of house, electricity connection, land ownership and dummies for } \\
\text { possesion of } 14 \text { types of household equipment }\end{array}$ & 0.000 & 1.893 \\
\hline Relative income & $\begin{array}{l}\text { Dummy; } 1=\text { if income in June < income in September; } 0=\text { if income in June } \\
>=\text { income in September }\end{array}$ & 0.496 & 0.500 \\
\hline Farmer & Dummy; 1 = farmer; 0 = non farmer & 0.702 & 0.458 \\
\hline Negative shock from harvest & $\begin{array}{l}\text { Dummy; } 1 \text { = bad harvest reported as the major negative shock in the past } \\
\text { five years }\end{array}$ & 0.423 & 0.494 \\
\hline Position in the family & $\begin{array}{l}\text { Position of a woman in a family. Index calculated by principal component } \\
\text { analyses from seven questions on decision-making and five questions on } \\
\text { wife's beating. Minimum of the index is set to zero. The higher the index } \\
\text { value, the better the position. }\end{array}$ & 3.617 & 1.887 \\
\hline
\end{tabular}

